\title{
On electroconvulsive therapy in depression \\ - Clinical, cognitive and neurobiological aspects
}

\author{
Pia Nordanskog
}

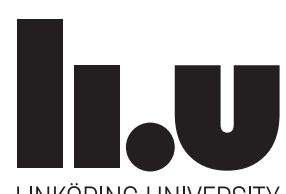

Faculty of Health Sciences

Department of Medical and Health Science

58185 Linköping

Linköping University, Sweden 
(C) Pia Nordanskog

Printed by LiU-Tryck, 2015

ISBN: 978-91-7519-026-6

ISSN: 0345-0082

Series: Linköping University Medical Dissertation No. 1468 
Medicus curat, natura sanat 


\section{CONTENTS}

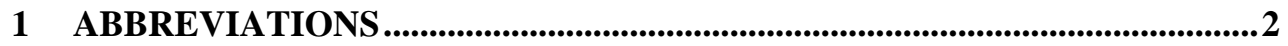

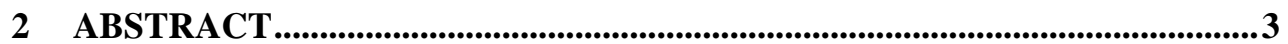

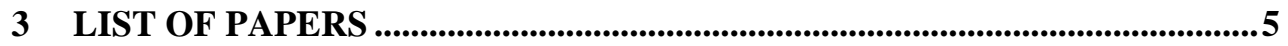

4 INTRODUCTION ......................................................................................................

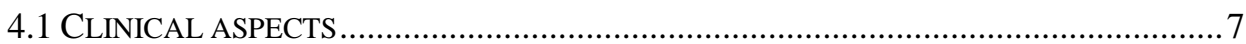

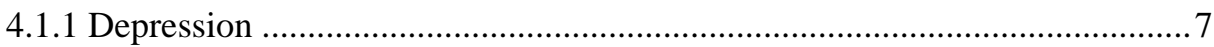

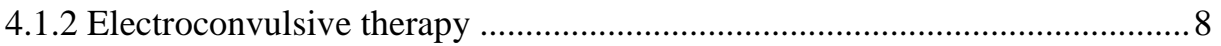

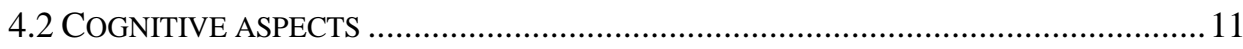

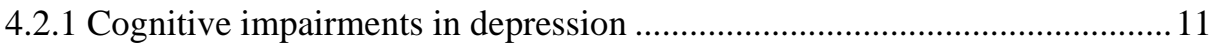

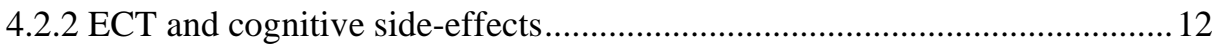

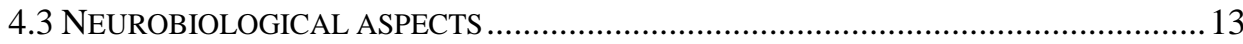

4.3.1 The neurobiological understanding of depression .........................................13

4.3.2 The neuroplasticity hypothesis in anti-depressive treatment.........................14

4.3.3 The neurobiological understanding of ECT .................................................. 15

5 SUMMARY AND SCOPE FOR EMPIRICAL STUDIES .................................17

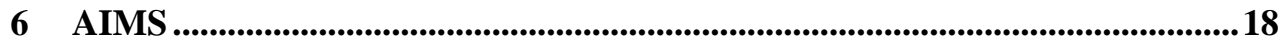

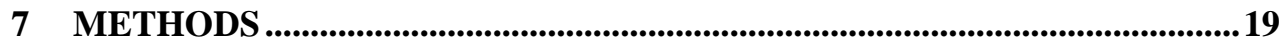

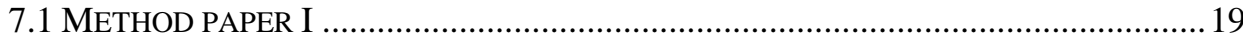

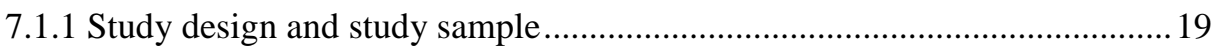

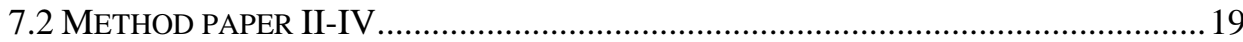

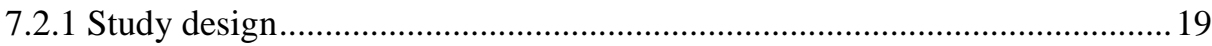

7.2.2 Divergences from study design and results presented in Paper II-IV ...........20

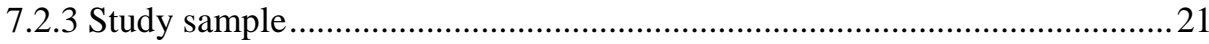

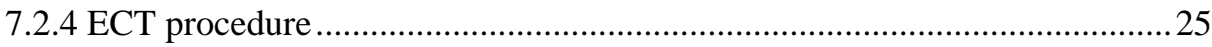

7.2.5 Psychiatric ratings and neuropsychological assessments ..............................25

7.2.6 MRI acquisition and post-processing ............................................................26

7.2.7 Hippocampal volume measurements (Paper II and III).................................2

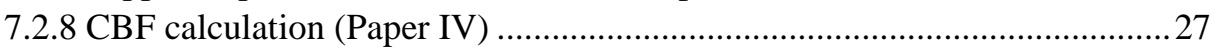

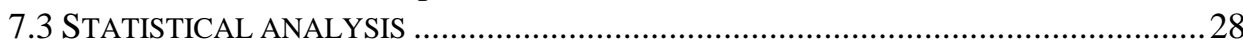

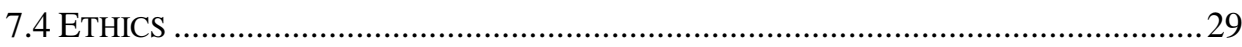

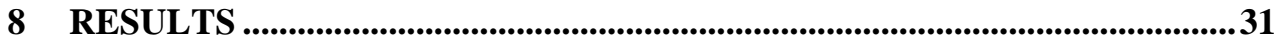

8.1 CURRENT USE AND PRACTICE OF ECT IN SWEDEN 2013 (PAPER I) ....................... 31

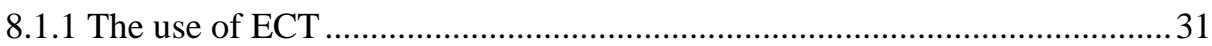

8.1.2 Indications for ECT ………….................................................................. 31

8.1.3 ECT organization and practice parameters...................................................

8.2 HIPPOCAMPAL VOLUME AND CBF IN RELATION TO CLINICAL AND COGNITIVE

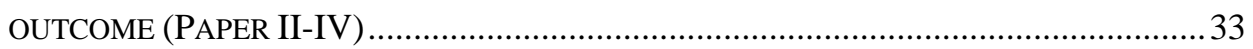

8.2.1 Antidepressant treatment response (Paper III and IV) ..................................33

8.2.2 Cognitive side-effects (Paper III) .................................................................. 34 


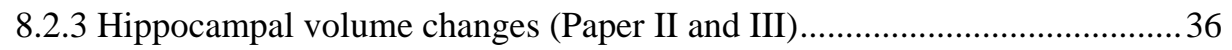

8.2.4 Hippocampal volume in relation to treatment effect (Paper III) ...................37

8.2.5 Hippocampal volume in relation to cognition (Paper III) ..............................37

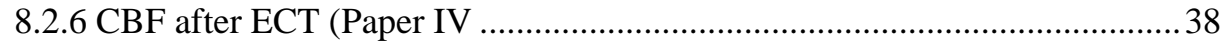

8.2.7 CBF after ECT, remitters vs. non-remitters (Paper IV) ..............................38

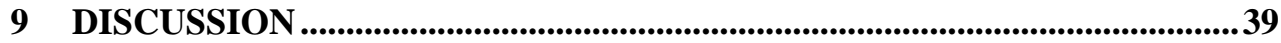

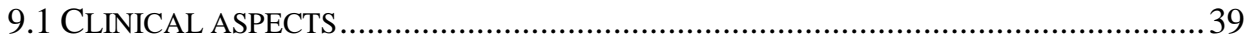

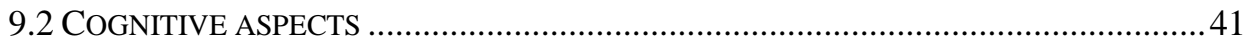

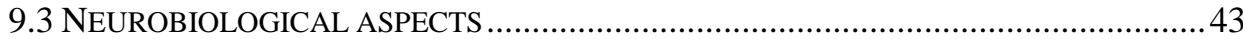

9.3.1 Hippocampal volume increase ........................................................... 43

9.3.2 Hippocampal volume in relation to treatment effect and cognitive findings 45

9.3.3 Significant shifts in perfusion ratios after ECT ......................................46

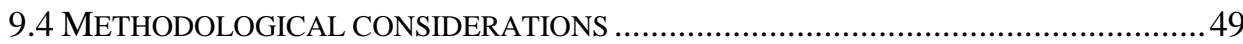

10 CONCLUSIONS AND FUTURE PERSPECTIVES...................................51

11 HOW DOES ECT WORK? ...........................................................................54

12 SAMMANFATTNING PÅ SVENSKA (SUMMARY IN SWEDISH) ...........56

13 TACK (ACKNOWLEDGEMENTS) .........................................................58

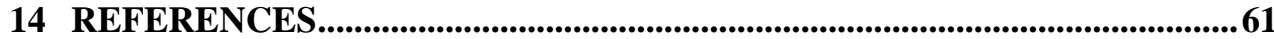




\section{ABBREVIATIONS}

\begin{tabular}{|c|c|}
\hline BDNF & Brain Derived Neurotrophic Factor \\
\hline $\mathrm{BP}$ & Bipolar disorder \\
\hline BT & Bitemporal \\
\hline CBF & Cerebral Blood Flow \\
\hline CMR & Cerebral Metabolic Rate \\
\hline CI & Confidence Interval \\
\hline DSC & Dynamic Susceptibility Contrast \\
\hline DSM IV & Diagnostic Statistical Manual, version IV \\
\hline ECS & Electroconvulsive Seizure \\
\hline ECT & Electroconvulsive Therapy \\
\hline FLAIR & Fluid Attenuation Inversion Recovery \\
\hline${ }^{1} \mathrm{H}-\mathrm{MRS}$ & Proton Magnetic Resonance Spectroscopy \\
\hline HAM-D & Hamilton Depression Rating Scale \\
\hline HAM-A & Hamilton Anxiety Rating Scale \\
\hline HPA-axis & Hypothalamic Pituitary Adrenal axis \\
\hline $\mathrm{Hz}$ & Hertz (unit of frequency) \\
\hline MADRS & Montgomery Asberg Depression Rating Scale \\
\hline MADRS-S & $\begin{array}{l}\text { Montgomery Asberg Depression Rating Scale } \\
\text { - self rating }\end{array}$ \\
\hline $\mathrm{mC}$ & milli Coulomb (unit of electric charge) \\
\hline MDD & Major Depressive Disorder \\
\hline MINI & Mini International Neuropsychiatric Interview \\
\hline MPRAGE & Magnetization Prepared Rapid Gradient Echo \\
\hline MRI & Magnetic Resonance Imaging \\
\hline ms & milli second \\
\hline PACS & Picture Archiving and Communication System \\
\hline PET & Positron Emission Tomography \\
\hline RAVLT & Rey Auditory Verbal Learning Test \\
\hline RCFT & Rey Complex Figure Test \\
\hline RUL & Right Unilateral \\
\hline SD & Standard Deviation \\
\hline SPECT & Single Photon Emission Computer Tomography \\
\hline $\mathrm{TE}$ & Echo Time \\
\hline TMT-A & Trail Making Test A \\
\hline TMT-B & Trail Making Test B \\
\hline TR & Repetition Time \\
\hline TRP & Treated Person Rate \\
\hline Тс-HMPAO & Technetium - Hexamethylpropyleneamine Oxime \\
\hline
\end{tabular}




\section{ABSTRACT}

Electroconvulsive therapy (ECT) is used worldwide to treat severe mental disorders. The most common mental disorder, and the third leading cause of disease burden in the world is depression. The clinical efficacy of ECT for severe depression is wellestablished. However, both the pathophysiology of depression and the mechanism of action of ECT remain elusive.

The main aims of this thesis are to address the following issues: 1) the use and practice of ECT in Sweden has not been systematically evaluated since 1975, 2) cognitive side-effects (memory disturbances) are a major concern with ECT and 3) the mechanism of action of ECT remain elusive. The neurobiological aspects of ECT focus on two hypotheses. First, the recent years' preclinical studies that have provided evidence that ECT induces hippocampal cell proliferation, including neurogenesis. Second, that enhanced functional inhibition of neuronal activity is a key feature.

Current use and practice of ECT in Sweden (paper I) is based on data from the national quality register for ECT, the mandatory patient register of the National Board of Health and Welfare and a survey. Treated person rate (TPR) in Sweden 2013 was found to be 41 individuals / 100 000, and thus unchanged since the latest systematic investigation in Sweden 1975. In more than $70 \%$ of treatment series the indication was a depressive episode. The selection of patients for ECT and treatment technique in Sweden was similar to that in other western countries, but the consent procedure and the involvement of nurses and nursing assistants in the delivery of ECT differ. Data also shows that there is room for improvement in both the specificity of use and availability of ECT.

The second study in this thesis is a longitudinal observational trial where 12 (paper II and III) and 14 (paper IV) patients with depression referred for ECT were investigated. Patients underwent a 3 T MRI structural scanning and DSC-MRI perfusion, a neuropsychological test battery and clinical ratings before ECT, within one to two weeks after ECT and after 6 and 12 months. In line with preclinical findings and the plasticity hypothesis of mechanism of action of ECT, the hippocampal volume increased after ECT in patients with depression. However, this increase was transient and returned to baseline levels within 6 months. No correlation was found between volumetric changes and clinical effect or cognitive outcome. Instead our results suggested an association to the number of treatments, without relation to the side of stimulation. A right-sided decrease in frontal blood flow distinguished remission from non-remission after ECT. There were significant impairments in verbal episodic memory and verbal fluency within one week after ending the ECT course, but these impairments were transient and no persistent cognitive impairments were seen during the follow-up. 
In summary, this thesis present the first update on the use and practice of ECT in Sweden in the last 40 years as well as a pioneering MRI-study on the hippocampal volume increase in the treatment of depression with ECT. Supportive to earlier findings we also found the cognitive side-effects that are measurable after ECT to be transient. Furthermore, we found that a decreased frontal blood flow is of importance for the anti-depressive response to ECT. 
Paper I: Nordanskog P, Hultén M, Landén M, Lundberg J, von Knorring L, Nordenskjöld A.

Electroconvulsive therapy in Sweden 2013: Data from the national quality register for ECT.

J ECT. 2015 May 12. [Epub ahead of print]

Paper II: Nordanskog P, Dahlstrand U, Larsson MR, Larsson EM, Knutsson L, Johanson A.

Increase in hippocampal volume after electroconvulsive therapy in patients with depression: a volumetric magnetic resonance imaging study.

J ECT. 2010 Mar; 26(1):62-7.

Paper III: Nordanskog P, Larsson MR, Larsson EM, Johanson A.

Hippocampal volume in relation to clinical and cognitive outcome after electroconvulsive therapy in depression.

Acta Psychiatr Scand. 2014 Apr; 129(4):303-11.

Paper IV: Nordanskog P, Knutsson L, Larsson E-M, Johanson A.

Relative decrease of frontal blood flow after electroconvulsive therapy in depression distinguishes remission: a perfusion MRI study

Manuscript. 


\section{INTRODUCTION}

\subsection{CLINICAL ASPECTS}

\subsubsection{Depression}

In ancient Greece, Hippocrates and his medical writers recognized and described melancholia as a prolonged condition of fear or sadness associated with "aversion to food, despondences, sleeplessness, irritability and restlessness". They were also convinced that this was a psychological manifestation of an underlying biological disturbance. Their hypothesis was that an imbalance in the four humors caused the illness, with an excess of the "black bile" (Greek: melaina chole) (Goodwin and Jamison 2007). More than two thousand years later, the description is still understandable with some of the ancient criteria yet incorporated in modern conceptualization of depression (APA 1994, WHO 2015). Even though the pathophysiology of depression remains elusive, and the theory of an excess of black bile is abandoned, modern research has confirmed the idea of an underlying disturbance in the normal biological equilibrium as a valid hypothesis.

In present conceptualization, depression is defined by an intraindividual change from previous habitual state to an inalterable and sustained depressed mood (feeling sad or empty) or marked loss of interest/pleasure (or both). This change must have a minimum of duration, and it should be unrelated to another medical condition or substance abuse, and cause significant distress or impairment in social, occupational or other important functioning. In addition to either the shift into a depressed mood or loss of ability to feel pleasure, there has to be disturbances in other aspects related to either emotional, cognitive or executive domains of human behavior as well as in the autonomic regulation of basal physiology (APA 1994, WHO 2015). The severely depressed patient shows symptoms of both hyper- and hypo functioning. For instance, objective slow-motion in movements and speech, a lack of initiative as well as a subjective experience of stress, inability to sleep and continuous and unstoppable ruminations.

Depression is a heterogeneous disorder. It can either occur as a major depressive disorder (MDD), with one single episode during a lifetime or be recurrent (also termed unipolar disorder). It can be a part of a manic-depressive disorder, where periods of depression and mania are alternating (also termed bipolar disorder). Depressive episodes also occur in the schizoaffective syndrome (defined as having psychotic symptoms and affective episodes which do not always occur simultaneously). The severity of a depressive episode varies from mild or moderate to severe states with melancholic, catatonic or psychotic features and suicidal ideation (Goodwin and Jamison 2007). 
Depression is currently one of the most disabling diseases and a significant burden to individuals and society (WHO 2008). Depression is the third leading cause of disease burden in the world and projections indicate that it will be the leading cause in developed countries in 2020 (SBU 2004, WHO 2008, Ferrari et al. 2013). Depression is also associated with excess mortality (Wulsin et al. 1999, Cuijpers et al. 2013).

Pharmacotherapy and psychotherapy are the most common treatments used for depression, but electroconvulsive therapy (ECT) remains an important and established alternative, especially in severe, psychotic depressive episodes and suicidal cases (The UK ECT Review Group 2003, SBU 2004).

\subsubsection{Electroconvulsive therapy}

\section{Origin of ECT}

The ability to restore a grumbled mind through repeated inductions of a seizure using chemical substances, convulsive therapy, has been known in medicine since the $18^{\text {th }}$ century, and its efficacy in states of acute psychosis is documented in several reports between 1751 - 1785 (Shorter and Healy 2007).

Ladislav Meduna successfully reintroduced the idea in the beginning of the $20^{\text {th }}$ century, based on clinical observations (a spontaneous seizure could cure a psychotic and delirious state) and neuropathological studies (patients with epilepsy had larger brains and more glia cells than normal and patients with schizophrenia had fewer). Both the clinical observations and the neuropathological studies led to the hypothesis that these disorders were antagonistic, and that they could be treated by inducing the antagonistic disorder respectively (i.e. epilepsy or schizophrenia, respectively). This also led to studies in which blood from patients with schizophrenia was unsuccessfully given to patients with epilepsy (Abrams 2002).

In 1938, Ugo Cerletti and Luigi Bini first showed that electric stimulation was a more optimal model for inducing seizures, as it was without the pain and fearful waiting for the seizure to be provoked (Faedda et al. 2010, Baran et al. 2012). In the following years, research has focused on further optimizing seizure induction and treatment course, reducing side effects, enhancing specificity of the indications for treatment, and understanding its mechanisms of action (Fink 2001).

In the most severe mental illnesses such as catatonia, malignant neuroleptic syndrome, delirious mania and acute psychosis, no other treatment has thus far been able to fully replace ECT as an important life-saving treatment. However, the most common indication for receiving ECT in the western world today is for depression (Leiknes et al. 2012). 


\section{ECT in depression}

Electroconvulsive therapy is a highly effective anti-depressive treatment in severe depression, especially in melancholic, psychotic, and suicidal cases (The UK ECT Review Group 2003). There is a distinct treatment effect, arriving earlier than pharmacological treatment (Pagnin et al. 2004). The remission rate for optimized ECT in psychotic depressed patients is very high, reaching greater than $90 \%$ (Petrides et al. 2001). According to results from the Consortium of Research in ECT (CORE-group), where $2 / 3$ of patients had non-psychotic depression, remission rate in the whole study sample (531 patients) was 64\%, and of those who completed the ECT course (394 patients) the remission rate was $84 \%$ (Kellner et al. 2006). In clinical settings, the remission rates tend to be lower (40-64\%), probably due to suboptimal treatments and patient selections for ECT (Prudic et al. 2004, SBU 2004). In some older studies using sham-ECT, there is an "improvement", "recovery" or response rate of $25-50 \%$, depending on different definitions in different studies, illustrating that every medical treatment contains a placebo effect, or an effect of other concomitant factors affecting outcome (e.g. hospitalization) (Rasmussen 2009).

If no maintenance treatment is offered, the relapse rate is also very high: almost half of all patients relapse, despite receiving pharmacotherapies, with the first 6 months being the period of greatest vulnerability (Jelovac et al. 2013, Fink 2014).

In the clinical treatment of depression the first sign of response to ECT is a disinhibition of the psychomotor retardation and an inhibition of the overactive autonomic stress regulation restoring the ability to sleep and eat. In clinical practice, these signs of clinical response provide important guidance in decision making during the treatment course. Another well-established variable related to the efficacy of treatment response is the quality of the induced seizure.

\section{ECT administration}

In the administration of ECT, an epileptic grand mal seizure is induced through the administration of electric pulses in a bidirectional manner, flowing between two electrodes applied to the skull during anesthesia and muscle relaxation. This grand mal seizure terminates spontaneously after 30-60 seconds. Electrodes can be applied either bilateral (bitemporal or bifrontal) or unilateral (d'Elia placement) to the skull. Stimulus dosage is determined by the electric charge, each pulse being $0.3-1 \mathrm{~ms}$ in duration, with a range of about 100 to 200 per second and a stimulus duration ranging from 2 to 8 seconds. Stimulus dosing is decided either by titration of the seizure threshold at the first treatment, or by formula-based dosing using age and gender for initial stimulus dose. Stimulus dose is also adjusted depending on electrode placement and in relation to state-related individual factors, such as concomitant pharmacological treatment, illness severity or the observed dynamic seizure 
physiology during treatment. The most commonly used interval for seizure induction is two to three days a week, but this can be individually adjusted in accordance to disease severity and tolerability respectively. A common treatment course is 6 to 12 treatments during 2 to 4 weeks (also termed “index ECT”). However, the treatment course is not pre-defined but continuously assessed and decided. Continuation ECT is used weekly or less frequently to prevent early relapse during the first six months after an index course. Sometimes ECT is even used as a maintenance treatment over more than six months. There are currently two devices that are most commonly used for ECT worldwide; the MECTA (MECTA Corp. Oregon, USA) and the Thymatron (Somatics LLS, Lake Bluff, Illinois, USA), although different regional devices exist (for example in Russia (Swartz 2009)).

Anesthesia during ECT is a complex procedure due to the goal of exciting the brain into a seizure immediately after sedation has been induced. The practice differs over the world and even between national sites as the optimal method for ECT-related anesthesia is still unclear (Lihua et al. 2014).

\section{Current use of ECT}

ECT is used worldwide. In a recent systematic overview, Leiknes et al. (Leiknes et al. 2012) showed a large global variation in the indications, treatment technique and availability of ECT. The availability in terms of treated person rate (TPR) varied from 1.1 to 54 per 100000 in various countries throughout the world.

In Sweden, all hospitals report to the mandatory patient register of the National Board of Health and Welfare. The register includes information on diagnosis and treatment (including treatment with ECT), and is organized according to personal identification number. Due to deficient reporting to this register, the Swedish national board of health and welfare could only estimate the TPR for ECT in Sweden 2010 to be 36.7 per 100000 (Socialstyrelsen 2010). After the report in 2010, awareness regarding the mandatory register increased, and reporting is believed to have been enhanced, as well. The use and practice of ECT in Sweden has not been systematically investigated since 1975, when 3482 patients (42 per 100 000) had received ECT (Frederiksen and D'Elia 1979). 


\subsection{COgNITIVE ASPECTS}

The abilities to encode, consolidate and retrieve stored information are necessary stages of memory processing and the experience of remembering.

Information about objects and events we experience, as well as where we experience them, is processed separately in different parts of the cerebral cortex, according to type of sensory information perceived. Cognitive domains involved in this encoding (and retrieving) of information are attention, processing speed and executive functions, which are localized mainly in the frontal lobes. Information is sent through the association areas to the medial temporal lobes. Within the temporal lobes is the hippocampus, an essential structure for the episodic or autobiographic memory. In this structure, cohesive memories of individual events are formed and consolidated, and if retrieved as an old memory, re-consolidated. Besides the medial temporal lobes, prefrontal regions are suggested to play an important role in strategies for learning and strategic control over the retrieval processes (Lezak 2012, Preston and Eichenbaum 2013)

Numerous divisions and subclassifications of the memory systems have been proposed. However, in clinical settings the dual conceptualization into non-declarative and declarative memory is the most common. The non-declarative, or implicit, memory is defined as knowledge that is expressed without awareness. Declarative, or explicit, memory is the intentional recall or recognition of previous experiences, and is further divided into semantic (fact) memory and episodic (or autobiographic) memory. There is a time-dependent dynamic process in the autobiographical memory system. Personal memories are constantly constructed and re-constructed, which results in a lack of consistency over time. Existing literature suggests that $28 \%$ to $40 \%$ of initially encoded and consolidated information is to be expected to be lost (forgotten) within 1 week to 3 months, and then appears to be relatively stable, at least up to one year (Semkovska and McLoughlin 2013).

Standardized neuropsychological assessments provide a tool to objectively analyze and categorize functioning in different cognitive domains involved in memory related processes, also providing normative data for inter-individual comparison. In these assessments, each cognitive domain is investigated according to functioning for a specific type of impairment and corresponding brain region.

\subsubsection{Cognitive impairments in depression}

Cognitive dysfunction, manifested as memory disturbances related to impairments in focused attention and decision-making (executive functions), is a state-related dysfunction and one of the formal diagnostic criteria in depression (APA 1994). Studies provide evidence to suggest that depression is in fact associated with a global 
cognitive dysfunction affecting various cognitive domains. (Murrough et al. 2011, Hasselbalch et al. 2012, Lee et al. 2012, Bora et al. 2013, Wagner et al. 2015). Cognitive deficits are related to the severity of the depressive episode and are more prevalent among patients with psychotic or melancholic features during their depressive episode (Bora et al. 2013, Hasselbalch et al. 2013). Increasing evidence suggests that at least some of this cognitive dysfunction remains even after remission (Hasselbalch et al. 2012, Bora et al. 2013)

Depression might also interfere with the motivational aspects of memory such that the patient puts less effort into necessary recall. The divergence in findings and lack of consensus according to the magnitude and makeup of cognitive dysfunctions during depression may be due to differences in discrete, yet uncategorized subgroups of depression, even beyond the two major groups of manic-depressive disorders and depressive disorders (Lezak 2012).

\subsubsection{ECT and cognitive side-effects}

During ECT, acute disorientation (postictal confusion) is well-documented and usually brief (hours). Significant changes in memory associated with ECT that have raised concerns are deficits in the retention of newly learned information during and after ECT (anterograde amnesia), as well as deficits in the recall of information learned before the treatment course (retrograde amnesia).

According to a recent meta-analysis of 84 studies (2981 patients), significant grouplevel impairments (mainly referring to episodic memory and executive functioning) is only detectible within 15 days after the ECT course has ended (Semkovska and McLoughlin 2010). This impairment can explain the anterograde amnesia in ECT, and thus suggest that it is a consequence of ECT, however transient. The question about the demonstration and progression of the autobiographic retrograde amnesia after ECT is more complex. Some authors state that dense retrograde amnesia in the absence of any problems with anterograde memory is highly uncommon, and as such should raise the question of other psychiatric or psychological factors at play (Kritchevsky et al. 2004, Stracciari et al. 2008). Others state that ECT, to some extent, cause permanent autobiographic retrograde amnesia (Sackeim et al. 2007). Notably, measuring retrograde autobiographic memory through self-report questionnaires includes difficulties in validity and reliability. In the ECT literature this far, unfortunately, commonly used instruments assessing retrograde amnesia have not been appropriately validated, and studies on autobiographic retrograde memory in relation to ECT are yet to be conducted (Semkovska and McLoughlin 2013). 


\subsection{NEUROBIOLOGICAL ASPECTS}

\subsubsection{The neurobiological understanding of depression}

The heterogeneity of the clinical manifestations of depression implies a pathophysiology compromising multiple neural substrates and mechanisms. Current conceptual framework suggests a functional imbalance in specific neurocircuits centrally involved in the control of emotion and emotion-related behavior, cognitive processes, and default network function (Maletic et al. 2007, Price and Drevets 2010).

Previous studies on functional imaging during depression have presented a diverse and complex picture (Drevets et al. 2008). Although many inconsistencies exist, a common finding across studies is a decrease in cerebral blood flow (CBF) or cerebral metabolic rate (CMR) during depression, especially in the frontal and prefrontal regions (Silfverskiold et al. 1986, Awata et al. 2002, Navarro et al. 2004, Takano et al. 2006, Kohn et al. 2007). A more novel method for understanding neuronal activity during depression is functional resting state MRI (fMRI). Although studies are sparse, evidence of disturbed connectivity in subcortical neurocircuits during depression (Sheline et al. 2010) support the suggested pathophysiological concept of depression as a functional imbalance in specific neurocircuits.

The corresponding biological pathology to this hypothesized functional imbalance is complex. Chemical imbalances in neurotransmitter systems, neuroendocrine disturbances and inflammatory processes have all been proposed as role players in this shift from functional homeostasis (Maletic et al. 2007). The last decade of research in mood disorders has also revealed impaired structural plasticity as a biological pathology corresponding to depression, referred to as the "neuroplasticity theory" (Duman 2004, Pittenger and Duman 2008). The hippocampus is primarily known for its role in learning and memory, but also has an important role in general cognition, mood regulation and response to stress (Morris 2006). Meta-analyses of structural imaging studies conclude that patients with major depressive disorder (MDD) have smaller hippocampal volume compared to healthy subjects (Sheline et al. 1999, MacQueen et al. 2003, Campbell et al. 2004, Videbech and Ravnkilde 2004, MacQueen and Frodl 2011). In addition, both pre-clinical and post-mortem studies report findings of reduced cell proliferation (including reduced neurogenesis, changes in neuropil and glial cell number and reduced dendritic complexity) correlating to stress and depression in the hippocampus (McEwen 2005, Czeh and Lucassen 2007, Pittenger and Duman 2008). 


\subsubsection{The neuroplasticity hypothesis in anti-depressive treatment}

In line with this hypothesis of impaired neuroplasticty as a pathophysiological mechanism in depression, pre-clinical reports have repeatedly demonstrated induction of increased cell proliferation in the hippocampus as a consequence of anti-depressive treatments. This was first shown with electroconvulsive seizures (Madsen et al. 2000, Malberg et al. 2000, Kozorovitskiy and Gould 2003, Santarelli et al. 2003, Berton and Nestler 2006, Perera et al. 2007). This influence on cell proliferation in the hippocampus (which, besides neurogenesis also includes angiogenesis, glia cell activation and synaptogenesis (Hellsten et al. 2005, Chen et al. 2009, Jansson et al. 2009)) suggests that an anti-depressive treatment might exert its behavioral effects through cytogenetic-dependent pathways (Duman et al. 2001, DeCarolis and Eisch 2010). Still, there are pre-clinical studies within this field with conflicting findings, suggesting that hippocampal neurogenesis is not required for all behavioral effects. In summary, the present evidence indicates that hippocampal neurogenesis may be involved in the treatment of depression but not necessarily in its pathology (Sahay and Hen 2007, DeCarolis and Eisch 2010).

Due to methodological problems, translation of these pre-clinical findings to human findings is difficult. Human data on neurogenesis has been sparse, but the evidence that does exists suggests that neurogenesis within the hippocampus persists into adulthood (Eriksson et al. 1998, Manganas et al. 2007, Boldrini et al. 2009, Spalding et al. 2013).

One way of approaching the neuroplasticity hypothesis in anti-depressive treatments is to investigate changes in biomarkers of proliferation, such as the brain derived neurotrophic factor, BDNF. There is some clinical evidence pointing to a positive correlation between levels of BDNF and anti-depressive treatment response (Shimizu et al. 2003, Bocchio-Chiavetto et al. 2006, Marano et al. 2007, Machado-Vieira et al. 2009, Piccinni et al. 2009).

A second way of approaching the potential role of cell proliferation in the treatment of depression is by measuring treatment-related volume changes in hippocampus with imaging analysis. Until recently, these changes had only been shown in a few clinical studies (Frodl et al. 2008, Ahdidan et al. 2011, Schermuly et al. 2011), but independent of response rate. Other studies had failed to find an association between hippocampal volume changes and anti-depressive treatment (Vythilingam et al. 2004). To what extent structural changes in the hippocampus are a clinically important target for treatment of depression remains elusive and questioned (Henn and Vollmayr 2004, DeCarolis and Eisch 2010). 


\subsubsection{The neurobiological understanding of ECT}

A generalized seizure induces a vast array of different changes in each hierarchical level of brain function, from the intracellular molecular systems to the complex assemblies of neuronal circuits. This multimodal mechanism of action might be one explanation for the varied clinical effects of ECT in very different clinical syndromes, such as severe depression and manic psychosis. It might also explain the huge variety of neurobiological changes that have been found in studies of ECT, ranging from enhancing serotonergic transmission and activating the mesocorticolimbic dopamine system, affecting the glutamate to GABA balance, restoring neuroendocrine function (reversal of HPA axis derangement) and changing functional activity in different brain regions (Swartz 2009, Bolwig 2011). The provoked seizure results in a sudden, endogenous initiated, cerebral activity inhibition, which then ends the seizure (ictal suppression). This sudden inhibition is followed by a period of postictal suppression of cerebral activity. During the course of treatment, the resistance against seizure induction successively rises during the treatment course, i.e. the seizure threshold increases (Duthie et al. 2015). This, coupled with the findings of a correlation between postictal suppression and clinical efficacy constitute the anticonvulsant hypothesis of mechanism of action of ECT (Sackeim 1999, Duthie et al. 2015). Current research has also put forth the neuroplasticity hypothesis, with evidence from animal models indicating a role in cell proliferation, including neurogenesis and synaptogenesis in the hippocampus (Madsen et al. 2000, Hellsten et al. 2002, Hellsten et al. 2005, Kaae et al. 2012) (see also paragraph above). 


\section{SUMMARY AND SCOPE FOR EMPIRICAL STUDIES}

Depression is currently the third most common source of burden of disease in the world, producing a significant burden to individuals and society. It is a disease with excess mortality rate. Still, the pathophysiology of depression and the clinically relevant targets for its treatment remain elusive. Electroconvulsive therapy has the power to provide rapid relief of the most severe symptoms in depression and can induce remission. Understanding the underlying neurobiological target (or targets) responsible for this treatment effect is essential for optimizing and developing novel and effective treatments. It may also elucidate important information regarding the pathophysiology of disorders treatable with ECT and, just as importantly, meet the need of explaining how ECT works to the patients.

To further investigate the neurobiological mechanisms of ECT in depression, this thesis builds one of its research questions on evidence from animal models. These findings indicate that electrically induced seizures result in cell proliferation, including neurogenesis, glia genesis, angiogenesis and synaptogenesis, in the hippocampus. We raised the question whether this could be translatable as a visible volume increase of the hippocampus in humans with depression receiving ECT. Furthermore, if a volume increase was visible, was it associated with anti-depressive efficacy? In addition, the role of correcting an imbalance in neurocircuits has also been proposed as an important mechanism of action of ECT, and the anticonvulsant hypothesis of mechanism of action of ECT suggests that a key feature in the therapeutic effect is an enhanced functional inhibition. Therefore, using the cerebral blood flow as a suggested marker for neuronal activity, the potential activity related changes can be elucidated and associations to clinical parameters investigated.

The use of ECT is partly restricted due to its cognitive side effects and the question of whether they are fully reversible or not. The question of cognitive side-effects and the judgment between risk and benefit of ECT needs further attention; both due to the risk of overuse of a method with potentially harmful side-effects and to the risk of underuse of an effective treatment due to magnified apprehension of cognitive sideeffects. We wanted to further explore these side-effects, their duration and reversibility, as well as their relation to neurobiological markers.

This difficult risk-benefit balance in the everyday clinical setting might be an important cause of the variation in the rate of use over time, as well as regional traditions of rate of use both within and between countries throughout the world. Forty years have passed since the use and practice in Sweden was systematically investigated and presented. Providing data on the use and practice of ECT is of importance for quality assurance reasons (e.g. is the use in line with present knowledge of the risk-benefit balance) as well as elucidating the possible need for a more precise clinical guidance. 


\section{AIMS}

The main aim of this $\mathrm{PhD}$ thesis was to elucidate clinical, cognitive and neurobiological aspects of ECT.

The specific aims of each paper presented in this thesis were:

Paper I To explore the current use of ECT in Sweden; the rate of use and its relation to national prevalence data of disorders treatable with ECT, characteristics of the ECT population, and how the treatment is practiced.

Paper II To determine if hippocampal volume, measured on MRI, changes immediately after a course of ECT in patients with depression.

Paper III To study the longitudinal course of hippocampal volume within one year after ECT. To describe cognitive side-effects in the short- and long-term perspective, and to determine whether changes in hippocampal volume are related to clinical and/or cognitive outcome.

Paper IV To determine functional changes in blood flow before and after ECT and its relation to treatment outcome. 


\section{METHODS}

\subsection{METHOD PAPER I}

\subsubsection{Study design and study sample}

Paper I is an observational, descriptive national cross-sectional study, based on two registers and a questionnaire.

In 2008, a regional ECT register was started in three counties in Sweden. As the National Board of Health and Welfare and the Swedish Psychiatric Association considered it important to document the use of ECT in Sweden in more detail, the regional register was expanded to a national quality register in 2011, with support from the Swedish Association of Local Authorities and Regions. One of the aims of the national quality register for ECT is to enable monitoring of the Swedish clinical guidelines for ECT issued in 2014 (Nordanskog and Nordenskjold 2014). The register holds detailed information on patient characteristics, severity of symptoms, indications for therapy, the electrical stimulus and seizures, course of treatment, pharmacotherapy (including the post-ECT medication used to reduce the risk of relapse) and side effects. The register is used for both quality assurance and for research. It is a non-mandatory register and every patient has the possibility to decline participation. In this study, we used the 2013 data from the national quality register on patient characteristics, indications for therapy and treatment parameters and data from the 2013 mandatory national patient register on diagnoses, hospitalization, and ECT. Information from the mandatory patient register and the national quality register for ECT was combined to identify all patients treated with ECT in Sweden in 2013.

In addition, all hospitals providing ECT in Sweden during 2013 responded to a questionnaire to survey the devices used and the organization.

\subsection{METHOD PAPER II-IV}

\subsubsection{Study design}

Papers II-IV are based on an observational study with a within-subjects, prospective longitudinal design and a convenient sampling method. We wanted to investigate immediate and long-term, within-subject changes in a naturalistic setting, for which a longitudinal observational design was considered as preferable, with repeated measurements during one year. We did not interfere with any clinical decision (i.e. neither ECT nor pharmacological interventions). 
Inclusion criteria were adult (age 18 year and forward) inpatients referred for ECT by their responsible psychiatrist and diagnosis of a depressive episode (unipolar or bipolar) according to DSM IV (APA 1994) and the Mini International

Neuropsychiatric Structured Interview (MINI) (Sheehan et al. 1998). Exclusion criteria were ECT during the past 12 months, substance abuse, involuntary care, pregnancy, life-threatening somatic disease, inability to give informed consent or contraindication to MRI.

Assessment time-points in the study protocol in paper II-III were set to within one week before ECT and within one week after ECT, after a minimum of 6 months and a minimum of 12 months after baseline. At each assessment point, psychiatric ratings, neuropsychological assessments, blood sample, and MRI were performed (Table 1). During the sample period, we did not succeed in having an MRI assessment within one week after ECT in all subjects. When analyzing the perfusion data (paper IV) we decided to also include subjects who had been investigated within up to two weeks after ECT.

Table 1. Study design.

\begin{tabular}{|l|l|l|l|l|}
\hline & $\begin{array}{l}\text { Before } \\
\text { ECT }\end{array}$ & $\begin{array}{l}\text { After } \\
\text { ECT }\end{array}$ & $\begin{array}{l}\text { After } \geq 6 \\
\text { months } \\
(\mathbf{m}=7)\end{array}$ & $\begin{array}{l}\text { After } \geq 12 \\
\text { months } \\
(\mathbf{m}=13.5)\end{array}$ \\
\hline Clinical data (incl. MINI) & $*$ & $*$ & $*$ & $*$ \\
\hline $\begin{array}{l}\text { Rating scales } \\
\text { (MADRS/-s, HAM-D, HAM-A) }\end{array}$ & $*$ & $*$ & $*$ & $*$ \\
\hline Neuropsychological assessments & $*$ & $*$ & $*$ & $*$ \\
\hline $\begin{array}{l}\text { MRI structural scanning, } \\
\text { perfusion and DTI }\end{array}$ & $*$ & $*$ & $*$ & $*$ \\
\hline $\begin{array}{l}\text { Biochemical analysis } \\
\text { BDNF, Folic acid and Homocystein }\end{array}$ & $*$ & $*$ & $*$ & $*$ \\
\hline
\end{tabular}

$\mathrm{m}=$ mean, MINI = Mini International Neuropsychiatric Rating Scale, MADRS = Montgomery

Asberg Rating Scale $/ \mathrm{s}=$ self-rating, $\mathrm{HAM}=$ Hamilton rating scale $\mathrm{D}=$ Depression and $\mathrm{A}=$ Anxiety, $\mathrm{MRI}=$ magnetic resonance imaging, $\mathrm{DTI}=$ diffusion tensor imaging, $\mathrm{BDNF}=$ Brain Derived Neurotrophic Factor

\subsubsection{Divergences from study design and results presented in Paper II-IV}

In the study design we first intended to use two different rating scales for depression: the MADRS (Montgomery and Asberg 1979) and the Hamilton depression and anxiety rating scales (HAM-D and HAM-A) (Hamilton 1959, Hamilton 1960). However, during the study, we finally decided to use only MADRS due to the risk of bias when using two different rating scales in the analysis.

Results from the diffusion tensor imaging (DTI) is in progress and are not further discussed in this thesis. 
The analysis of BDNF was invalid due to inconsequent sampling method and lack of handling the blood samples in a proper way. When analyzing the samples, we discovered that our samples lacked constant diurnal time point and that several samples had arrived to the laboratory without being put in ice in accordance to study protocol. This analysis was therefore condemned as failed data and could not be used in our study as intended.

Folic acid and homocysteine were in the protocol as a hypothesis of relation to antidepressant efficacy. The final sample did not hold necessary power for the statistical analysis.

\subsubsection{Study sample}

Subjects were consecutively recruited inpatients referred for ECT by their psychiatrist at Lund University Hospital Psychiatry Clinic, Sweden (enrolment period April 2005 to March 2009). Information about the study and how to contact the research group was spread to all staff-members at the clinic. Patients referred for ECT were screened for inclusion by one person in the research team and asked for participation. Screening included an in-house developed screening manual for inclusion and exclusion criteria, demographic data, information from the medical record, and a MINI interview. All patients had been clinically investigated including normal physical examination and routine blood sampling.

Twenty patients were recruited to the study at baseline and at the twelve month follow-up assessment, seven subjects remained in the study (Figure 1). Demographic data concerning the subjects are shown in Table 2. Paper II + III contains subject number 1-12, paper IV subject number 1-14. 


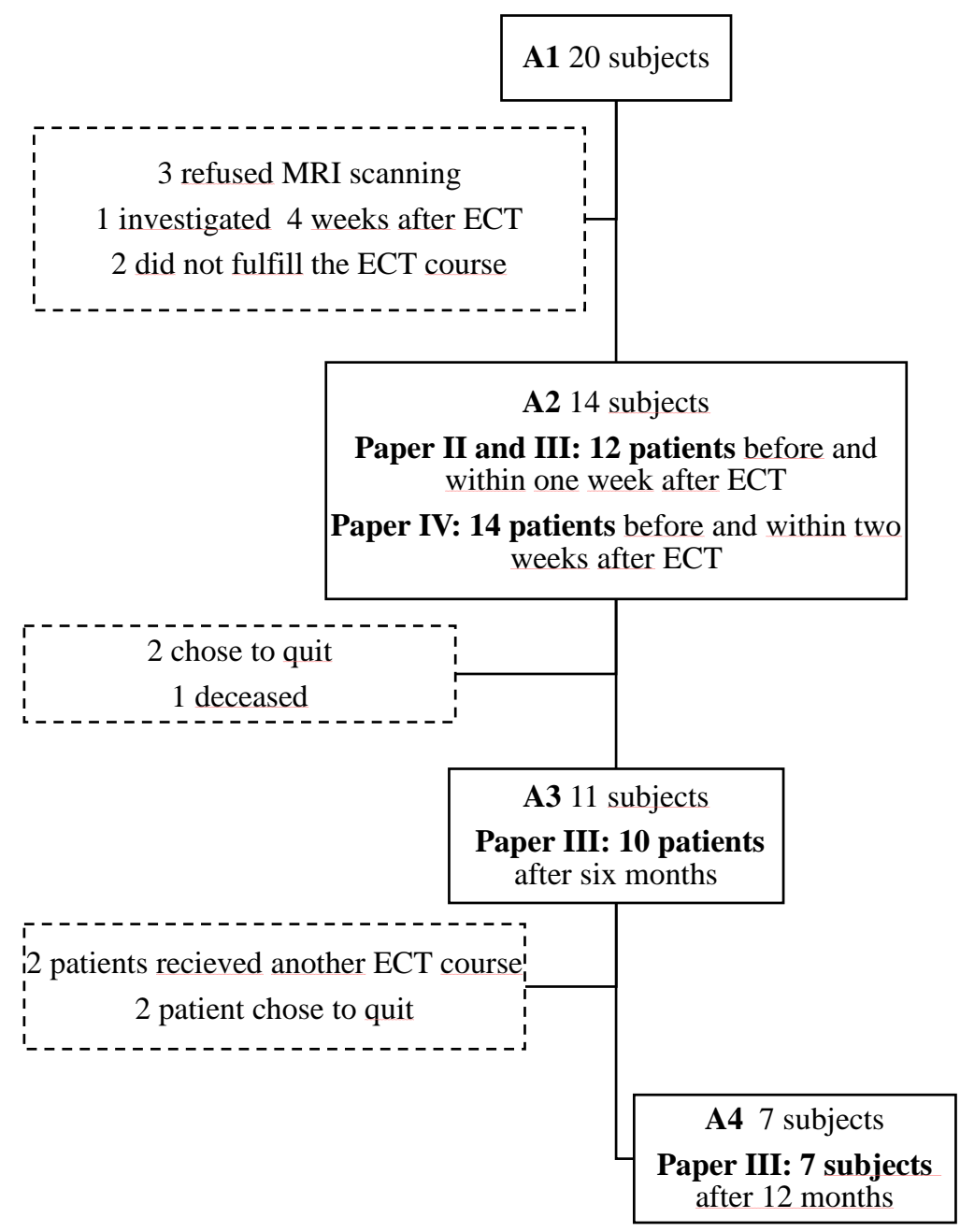

Figure 1. Study sample flow chart paper II-IV. 
Mean age in all 14 subjects presented in paper IV was 44.4 years (CI 19-85, SD 19.1), $60 \%$ were women and they had a mean of 9.8 ECT (CI 5-15, SD 3.0). Episode duration was 6.3 months (CI 1-15, SD 4.2). The interval between last ECT and postECT assessment were 4.5 days (CI 1-14, SD 3.5) and mean interval between pre and post MRI were 30 days (CI 16-42, SD 8.0). All patients had clinically normal morphological MRI scans on all occasions.

Table 2. Demographics.

\begin{tabular}{|l|l|l|l|l|l|l|l|l|l|}
\hline Case & Sex & $\begin{array}{l}\text { Age at } \\
\text { first } \\
\text { episode } \\
\text { (year) }\end{array}$ & $\begin{array}{l}\text { Age at } \\
\text { inclusion } \\
\text { (year) }\end{array}$ & $\begin{array}{l}\text { Diagnosis } \\
\text { (DSM } \\
\text { IV) }\end{array}$ & $\begin{array}{l}\text { Current } \\
\text { episode } \\
\text { (months) }\end{array}$ & $\begin{array}{l}\text { Number } \\
\text { of ECT }\end{array}$ & $\begin{array}{l}\text { Electrode } \\
\text { Placement }\end{array}$ & $\begin{array}{l}\text { Interval } \\
\text { last } \\
\text { ECT- } \\
\text { A2 } \\
\text { (days) }\end{array}$ & $\begin{array}{l}\text { Interval } \\
\text { A1-A2 } \\
\text { (days) }\end{array}$ \\
\hline 1 & M & 30 & 34 & BP II & 8 & 12 & RUL & 3 & 31 \\
\hline 2 & F & 15 & 23 & BP II & 6 & 8 & RUL & 5 & 27 \\
\hline 3 & F & 30 & 65 & MDD & 4 & 6 & RUL & 3 & 19 \\
\hline 4 & F & 22 & 33 & MDD & 8 & 9 & RUL & 2 & 21 \\
\hline 5 & F & 13 & 19 & MDD & 1 & $12^{*}$ & $\begin{array}{l}\text { RUL 1-11 } \\
\text { no12 BT }\end{array}$ & 5 & 36 \\
\hline 6 & M & 18 & 36 & MDD & 11 & 9 & RUL & 1 & 21 \\
\hline 7 & F & 62 & 67 & MDD & 1 & 8 & RUL & 5 & 27 \\
\hline 8 & F & 18 & 28 & MDD & 7 & 13 & RUL & 3 & 34 \\
\hline 9 & F & 28 & 61 & BP I & 15 & $15^{*}$ & $\begin{array}{l}\text { RUL, no } \\
4-15 \text { BT }\end{array}$ & 2 & 42 \\
\hline 10 & F & 37 & 42 & BP I & 6 & 6 & RUL & 1 & 16 \\
\hline 11 & F & 18 & 34 & BP II & 4 & 11 & RUL & 7 & 35 \\
\hline 12 & F & 20 & 41 & MDD & 3 & 13 & RUL & 7 & 36 \\
\hline 13 & M & 31 & 84 & MDD & 2 & $5 *$ & RUL & 14 & 41 \\
\hline 14 & M & 33 & 55 & MDD & 12 & 10 & RUL & 9 & 31 \\
\hline
\end{tabular}

$\mathrm{M}=$ male, $\mathrm{F}=$ female, $\mathrm{BP}=$ bipolar disorder I and II respectively, most recent episode depressed. $\mathrm{MDD}=$ major depressive disorder. ECT = electroconvulsive therapy. $\mathrm{RUL}=$ right unilateral electrode placement. $\mathrm{BT}=$ bitemporal electrode placement. A1= assessment one, before ECT, A2= assessment two, immediate after ECT.

* Prior ECT 12-36 months before current episode.

During ECT, patients continued to take their medication (Table 3), which consisted of different antidepressants with add-on therapy; selective serotonin reuptake inhibitors (8/14) serotonin-norepinephrine reuptake inhibitors (5/14), tetracyclic antidepressants (7/14) and tricyclic antidepressants (1/14). All patients except one were taking antidepressant medication continuously during the 12 months follow-up. Twelve of the subjects had used antidepressant medication for more than 6 months prior to inclusion, and two less than 6 months. 
Table 3. Psychopharmacological treatment at inclusion and changes during follow-up

\begin{tabular}{|c|c|c|c|c|c|}
\hline \multirow[t]{2}{*}{ Case } & \multicolumn{5}{|c|}{ Antidepressant, mood stabilizer and antipsychotic mg/day } \\
\hline & A1 & 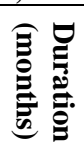 & A2 & A3 & A4 \\
\hline 1 & $\begin{array}{l}\text { Fluo } 80 \mathrm{mg} \\
\text { Mir } 30 \mathrm{mg} \\
\text { Hal } 1.5 \mathrm{mg}\end{array}$ & $>6$ & $\begin{array}{l}\text { Fluo } 80 \mathrm{mg} \\
\text { Mir } 30 \mathrm{mg} \\
\text { Hal } 1.5 \mathrm{mg}\end{array}$ & $\begin{array}{l}\text { Fluo } 80 \mathrm{mg} \\
\text { Ola } 15 \mathrm{mg}\end{array}$ & \\
\hline 2 & $\begin{array}{l}\text { Ser } 125 \mathrm{mg} \\
\text { Fluo } 20 \mathrm{mg} \\
\text { Val } 600 \mathrm{mg}\end{array}$ & $>6$ & $\begin{array}{l}\text { Fluo } 60 \mathrm{mg} \\
\text { Val } 1500 \mathrm{mg}\end{array}$ & $\begin{array}{l}\text { Fluo } 60 \mathrm{mg} \\
\text { Flup } 0.5 \mathrm{mg}\end{array}$ & $\begin{array}{l}\text { Fluo } 40 \mathrm{mg} \\
\text { Flup } 0.5 \mathrm{mg}\end{array}$ \\
\hline 3 & $\begin{array}{l}\text { Fluo } 40 \mathrm{mg} \\
\text { Mir } 15 \mathrm{mg}\end{array}$ & $>6$ & $\begin{array}{l}\text { Fluo } 40 \mathrm{mg} \\
\text { Mir } 15 \mathrm{mg}\end{array}$ & Fluo $40 \mathrm{mg}$ & $\begin{array}{l}\text { Fluo } 40 \mathrm{mg} \\
\text { Mir } 15 \mathrm{mg}\end{array}$ \\
\hline 4 & $\begin{array}{l}\text { Fluo } 40 \mathrm{mg} \\
\text { Mir } 30 \mathrm{mg}\end{array}$ & $>6$ & $\begin{array}{l}\text { Fluo } 40 \mathrm{mg} \\
\text { Mir } 30 \mathrm{mg}\end{array}$ & $\begin{array}{l}\text { Fluo } 20 \mathrm{mg} \\
\text { Ven } 150 \mathrm{mg} \\
\end{array}$ & $\begin{array}{l}\text { Fluo } 20 \mathrm{mg} \\
\text { Ven } 75 \mathrm{mg} \\
\end{array}$ \\
\hline 5 & Ven $150 \mathrm{mg}$ & $>6$ & Ven $150 \mathrm{mg}$ & $\begin{array}{l}\text { Ven } 300 \mathrm{mg} \\
\text { Lam } 100 \mathrm{mg}\end{array}$ & Ven $450 \mathrm{mg}$ \\
\hline 6 & $\begin{array}{l}\text { Ven } 225 \\
\text { Li } 168 \text { mg } \\
\text { Flup } 3 \text { mg }\end{array}$ & $>6$ & $\begin{array}{l}\text { Ven } 150 \\
\text { Li } 84 \text { mg } \\
\text { Flup } 3 \text { mg }\end{array}$ & $\begin{array}{l}\text { Ven } 300 \mathrm{mg} \\
\text { Li } 210 \mathrm{mg} \\
\text { Flup } 3 \mathrm{mg}\end{array}$ & $\begin{array}{l}\text { Ven } 300 \mathrm{mg} \\
\mathrm{Li} 210 \mathrm{mg} \\
\text { Lam } 50 \mathrm{mg}\end{array}$ \\
\hline 7 & Ven $150 \mathrm{mg}$ & 1 & Ven $150 \mathrm{mg}$ & Ven $225 \mathrm{mg}$ & Ven $225 \mathrm{mg}$ \\
\hline 8 & Mir 45 mg & $>6$ & Mir 45 mg & Ven $150 \mathrm{mg}$ & \\
\hline 9 & $\begin{array}{l}\text { Esc } 20 \mathrm{mg} \\
\text { Carb } 400 \mathrm{mg} \\
\text { Lam } 200 \mathrm{mg}\end{array}$ & $>6$ & $\begin{array}{l}\text { Esc } 20 \mathrm{mg} \\
\text { Lam } 200 \mathrm{mg}\end{array}$ & & \\
\hline 10 & Fluo $20 \mathrm{mg}$ & 0,5 & Fluo $20 \mathrm{mg}$ & $\begin{array}{l}\text { Fluo } 10 \mathrm{mg} \\
\text { Que } 10 \mathrm{mg}\end{array}$ & $\begin{array}{l}\text { No pharm. } \\
\text { treatment }\end{array}$ \\
\hline 11 & $\begin{array}{l}\text { Ven } 300 \mathrm{mg} \\
\text { Mir } 15\end{array}$ & $>6$ & $\begin{array}{l}\text { Ven } 225 \mathrm{mg} \\
\text { Mir } 30 \mathrm{mg}\end{array}$ & $\begin{array}{l}\text { Ven } 225 \mathrm{mg} \\
\text { Mir } 30 \mathrm{mg} \\
\text { Lam } 100 \mathrm{mg} \\
\text { Ola } 5 \mathrm{mg}\end{array}$ & \\
\hline 12 & $\begin{array}{l}\text { Cit } 20 \text { mg } \\
\text { Clom } 225 \\
\text { mg } \\
\text { Lam } 400 \text { mg }\end{array}$ & $>6$ & $\begin{array}{l}\text { Cit } 20 \mathrm{mg} \\
\text { Clom } 225 \mathrm{mg} \\
\text { Lam } 200 \mathrm{mg}\end{array}$ & & \\
\hline 13 & $\begin{array}{l}\text { Mir } 30 \mathrm{mg} \\
\text { Cit } 20 \mathrm{mg} \\
\text { Li } 42 \mathrm{mg}\end{array}$ & $>6$ & $\begin{array}{l}\text { Mir } 30 \mathrm{mg} \\
\text { Cit } 20 \mathrm{mg} \\
\mathrm{Li} 42 \mathrm{mg} \\
\text { Hal } 0.5 \mathrm{mg}\end{array}$ & & \\
\hline 14 & $\begin{array}{l}\text { Ven } 300 \mathrm{mg} \\
\text { Mir } 60 \mathrm{mg}\end{array}$ & $>6$ & $\begin{array}{l}\text { Ven } 225 \mathrm{mg} \\
\text { Mir } 75 \mathrm{mg}\end{array}$ & & \\
\hline
\end{tabular}

Fluoxetine (Fluo), Sertraline (Ser), Citalopram (Cit), Escitalopram (Esc)

Venlafaxine (Ven), Mirtazapine (Mir), Clomipramine (Clom), Lithium (Li), Valproate (Val), Lamotrigine (Lam), Quetiapine (Que), Olanzapine (Ola), Flup (Flupentixole), Haloperidol (Hal) 


\subsubsection{ECT procedure}

Electroconvulsive therapy (SpECTrum 5000Q, MECTA Corp. Oregon, USA) was administered three days a week at the Lund University Hospital ECT unit. Right unilateral (RUL) brief-pulse stimulation was applied to all patients except two, who also underwent bitemporal (BT) treatment (Table 2). Thiopental was used to induce anaesthesia (4-6 $\mathrm{mg} / \mathrm{kg}$ body weight, injected intravenously) and succinylcholine was used to ensure muscle relaxation (0.3-0.8 $\mathrm{mg} / \mathrm{kg}$ body weight). The initial stimulus dose was set according to age and gender, and then adjusted during the treatment period depending on seizure (monitored both with regard to the cerebral epileptic activity recorded by the encephalogram and the motoric seizure), treatment efficacy and side effects. The patient responsible psychiatrist made the decision regarding the total number of ECT based on experienced clinical judgement. Mean ECT parameters ( $\mathrm{n}=14)$ were as follows: $800 \mathrm{~mA}$, stimulation time $7.3 \mathrm{sec}$ (6-8 SD 1), pulse width $0.44 \mathrm{~ms}(0.3-0.6 \mathrm{SD} 0.12)$, frequency $71 \mathrm{~Hz}$ (33-93 SD 18) and charge $370 \mathrm{mC}$ (CI 127-627 SD 162). Mean seizure duration 35 sec (16-62 SD 13).

\subsubsection{Psychiatric ratings and neuropsychological assessments}

The severity of depression was rated using the MADRS (Montgomery and Asberg 1979) for clinical rating and self-rating (MADRS-S) (Svanborg and Asberg 1994) by one person in the research team. Remission was defined as a MADRS score of less than 12 points after treatment. For both MADRS and MADRS-S response was defined as a reduction in score of $50 \%$ or more in rating scores, and partial response as a reduction of $25-49 \%$.

The neuropsychological assessments were administered by experienced neuropsychologists. Vocabulary is a part of semantic memory, and was measured as a control for eventual bias as it correlates highly with both social class and education (Lezak 2012). The Rey Auditory Verbal Learning Test (RAVLT) was used to evaluate the different aspects of verbal episodic memory (Lezak 2012). We used "RAVLT Immediate" to assess the encoding of new verbal information, "RAVLT Retention" to measure the total amount of learning, "RAVLT Delayed" to evaluate the long-term recall memory and, finally, RAVLT Recognition, a test where a cue is added, making long-term recall less dependent on complex retrieval strategies. These tests are especially sensitive to hippocampal functioning, and it has been suggested that the left hippocampus is more involved than the right. Visual episodic memory was assessed by the Rey Complex Figure Test (RCFT) (Lezak 2012), in which the right hippocampus is believed to be more involved. The Trail Making Test B (TMT-B), the Stroop Test (also called the Colour Word Test) and Verbal Fluency (Lezak 2012) were used to assess executive functions. Digit Symbol, Digit Span (Wechsler 1958) 
and Trail Making Test A (TMT-A) were used to evaluate processing speed and attention/working memory. Spatial problem solving was performed with the Block Design Test (Wechsler 1958) and RCFT copying. All neuropsychological tests have normative data according to stanine points with reference interval 4-7 (RAVLT, RCFT, Verbal Fluency, Stroop, TMT-A and TMT-B) or scale points with reference interval 8-12 (Digit Symbol, Digit Span, Vocabulary, Block Design).

Assessments were administered on all four occasions except for the Block Design Test and RCFT, which were only administered at baseline and after 12 months in accordance to the recommendations in the test manual.

\subsubsection{MRI acquisition and post-processing}

All MRI examinations were performed with a 3T MRI scanner (Magnetom Allegra, Siemens AG, Erlangen, Germany). An axial T2-weighted fluid attenuation inversion recovery (FLAIR) sequence was obtained (repetition time TR/echo time TE $=10000$ $\mathrm{ms} / 101 \mathrm{~ms}$, inversion time TI = $2500 \mathrm{~ms}$, slice thickness $5 \mathrm{~mm}$, field of view $230 \mathrm{~mm}$, image matrix 320x256) to rule out pathological changes in the brain.

A coronal 3D magnetization prepared rapid gradient echo (MPRAGE) sequence covering the entire brain was obtained for hippocampal volume measurements, using the following parameters: flip angle $8^{\circ}$, TR/TE $=2500 \mathrm{~ms} / 4.38 \mathrm{~ms}, \mathrm{TI}=1100 \mathrm{~ms}$, slice thickness $1 \mathrm{~mm}$, field of view $256 \mathrm{~mm}$, image matrix 256×256. Using multiple gradients (MPRAGE) enables spatial information of the signals, allowing a three dimensional data acquisition. The MPRAGE sequence was obtained perpendicular to the hippocampus. Sagittal $1 \mathrm{~mm}$ slices were reconstructed from this sequence through the whole brain after scanning. The maximal permitted angle discrepancy between the two coronal MPRAGE sequences from the same patient was $5^{\circ}$, as measured by the line between anterior and posterior commissure. If this value was exceeded, new oblique coronal $1 \mathrm{~mm}$ slices were reconstructed from the original coronal 3D volume.

Analysis of cerebral blood flow was performed with gadolinium-based contrast agent at a dose of $0.1 \mathrm{mmol} / \mathrm{kg}$ body weight (Magnevist, Schering, Berlin, Germany) which was injected automatically at a rate of $5 \mathrm{~mL} / \mathrm{s}$ in an arm vein. The first passage of contrast agent bolus was monitored in 23 slices by use of a gradient echo echo-planar imaging (GRE-EPI) pulse sequence with flip angle 90, echo time $21 \mathrm{~ms}$, slice thickness $5 \mathrm{~mm}$ and image matrix $128 \times 128$. The temporal resolution was 1.5 seconds and 60 images per slice were recorded in the time series. 


\subsubsection{Hippocampal volume measurements (Paper II and III)}

The hippocampus was manually delineated on the coronal slices using a graphics tablet (Wacom Co. Ltd. Kita Saitama-Gun, Saitama Japan) together with a picture archiving and communication system (PACS) workstation. The area of each outlined region was calculated automatically. Standard atlases were used for anatomical guidelines (Naidich et al. 1987, Duvernoy 2005), together with the established criteria of Watson (Watson et al. 1992). The sagittal slices reconstructed from the coronal 3D volume were visualized simultaneously to improve the accuracy, especially with regard to delineation with the amygdala. Two raters, trained by experienced senior neuroradiologists, outlined both hippocampi before and after ECT. Reliability (kappa $>0.9$ ) was established by repeated measurements on multiple MRI scans of subjects not included in the study. The raters were blinded to the clinical outcome, but the date of scanning was visible on the scans. The raters did not assess the scans in consecutive order according to subject or date of scanning. In the two assessments in the follow-up period the hippocampi were outlined by one of the two raters.

\subsubsection{CBF calculation (Paper IV)}

CBF was calculated using Zierler's area to height relationship and the central volume theorem (Meier and Zierler 1954, Zierler 1965)

$$
C B F=\frac{\left(1-H_{\text {large }}\right) R_{\max } \int_{0}^{\infty} C(t) d t}{\rho\left(1-H_{\text {small }}\right) \int_{0}^{\infty} R(t) d t \int_{0}^{\infty} A I F(t) d t}
$$

$\mathrm{C}$ is the contrast-agent concentration in the tissue and AIF is the contrast agent concentration in a brain-feeding artery. The residue function R, i.e., the fraction of the injected tracer still present in the vasculature at time $t$ after an assumed arterial input of infinitely short duration, can be obtained by deconvolving the concentration time curve with the AIF. Rmax is the peak value of this function. Hlarge and Hsmall are the haematocrit values in large and small vessels, respectively, and $\rho$ is the wholebrain mass density. The value (1-Hlarge) $/[\rho(1-$ Hsmall $)]=0.705 \mathrm{~cm} 3 / \mathrm{g}$ was used in this study (Rempp et al. 1994). The deconvolution was done using a block-circulant singular value decomposition (Wu et al. 2003) and the AIF was retrieved from the middle cerebral artery branches in the Sylvian Fissure region.

For the evaluation of the CBF images the 23 slices were reconstructed to 10 slices and a comprehensive selections of region of interests (ROIs) were placed in the slices. 
The positioning of standard ROIs in the CBF map was accomplished by use of an inhouse-developed computed program (Knutsson et al. 2007) (Figure 2). The original subset of frontal and parietal ROIs (frontal orbital, frontal lateral and medial, parietal superior and inferior) in the CBF map were merged to frontal and parietal ROIs. The mean $\mathrm{CBF}$ value was divided by the whole brain $\mathrm{CBF}$ value to obtain the relative $\mathrm{CBF}$ in each region.

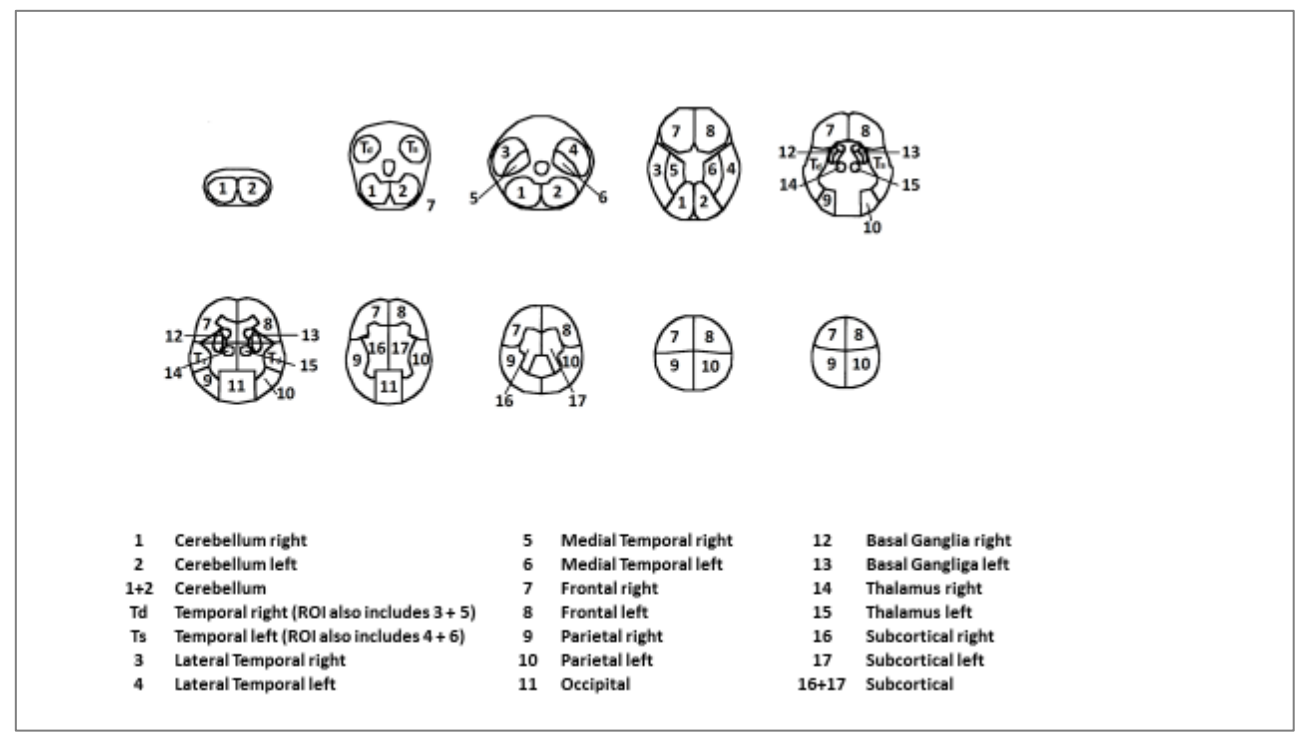

Figure 2. Region of Interest (ROI) in a schematic drawing of the reconstructed DSC perfusion MRI slices of the brain.

\subsection{STATISTICAL ANALYSIS}

SPSS version 21 (SPSS Inc, Chicago, III) was used for the descriptive statistical analysis in paper $\mathrm{I}$.

For the clinical, neuropsychological and hippocampal analyses in paper II and III, parametric test (Pearson dependent sample t-test) were used. To exclude the possibility of skewed variables influencing the results and to determine whether the low number of participants affected the results, all statistical analysis were also performed using a non-parametric test (Wilcoxon, Spearman). Comparison between the results of the parametric and non-parametric tests revealed no differences in significance / non-significance, so the use of parametric values was deemed adequate in this study.

For the hippocampal volume measurements, Pearson correlations were used to analyze the inter-rater reliability between the two raters. The left and right 
hippocampal volume of each patient was calculated by adding the area of the hippocampus on each slice into to a total sum. The total sum of the two raters was then added and divided by two to get a mean rating for each patient.

For the analysis of the within group changes in relative CBF before and after ECT in paper IV we used Wilcoxon signed rank test. For the in-between subgroup analysis we used the Mann Whitney U-test for two independent groups and the Pearson chi square test for binomial variables.

\subsection{ETHICS}

The Regional Ethical Vetting Board in Uppsala approved the study presented in paper I. The patients were informed about the quality register and had the option to decline participation.

The study presented in papers II-IV was approved by the Regional Ethical Review Board at Lund University, and all participants provided written informed consent. 


\section{RESULTS}

\subsection{CURRENT USE AND PRACTICE OF ECT IN SWEDEN 2013 (PAPER I)}

\subsubsection{The use of ECT}

In Sweden 2013, 41 per 100,000 inhabitants were treated with ECT (3972 patients). The proportion varied both according to site (ranged from 26 per 100000 to 62 per 100000 in different counties in Sweden) and age (from 0/100 000 in the age-group 014 years to 77/100 000 in the age-group 75-84).

Eighty-five percent of the patients treated with ECT in Sweden in 2013 opted to participate in national quality register (3246 patients, a total of 35875 ECT sessions divided into 3746 index series and 738 continuation series). The median age of the patients was 55 years (range 15 to 94), six of which were below 18 years of age and 20 were above 90 years of age. Of the included patients, $63 \%$ were women.

\subsubsection{Indications for ECT}

A depressive episode, including unipolar or bipolar at all degrees of severity, was the indication for ECT in approximately $70 \%$ of all treatment series. The most common indication for ECT in Sweden 2013 was unipolar severe depression (28\%). In $20 \%$ of the treatment series the indications for ECT were not listed in the Swedish clinical guidelines for ECT (Nordanskog and Nordenskjold 2014). The most common indications in this group were affective disorders not otherwise specified. The most common indications for ECT that are not recommended by the Swedish clinical guidelines were obsessive-compulsive disorder, anxiety disorders and emotionally unstable personality disorder.

According to the mandatory register, out of 4711 hospitalized patients that were treated for severe depression in 2013, 38\% received ECT. The proportion of severely depressed inpatients that received ECT was higher among women (40\%) than men (34\%). Based on the Swedish clinical guidelines for ECT, the method is a first-line treatment for catatonia, cycloid psychosis, psychotic depressions, puerperal psychosis, and malignant neuroleptic syndrome. In 2013, there were 1694 inpatients with one of these diagnoses, and 38\% of these received ECT. This proportion was higher among women 417/1 028 (41\%) than men 233/666 (35\%). Out of 29 inpatients below the age of 18 with one of these diagnoses, three received ECT (10\%).

13\% of the patients that received ECT in Sweden in 2013 were treated under the Swedish act on compulsory psychiatric care. 


\subsubsection{ECT organization and practice parameters}

According to the survey, all 56 hospitals provided ECT for outpatients and all hospitals except two provided ECT for inpatients. A few persons alternated to deliver the electrical stimulus in each of the 56 hospitals, and they had various training. Psychiatrists participated in delivering ECT in 21 hospitals, anesthesiologists participated in 2 hospitals, psychiatric residents participated in 11 hospitals, nurses participated in 49 hospitals and nursing assistants (unlicensed assistant personnel) participated in 20 hospitals.

The median number of treatments per index series was seven (interquartile range 69). Unilateral treatment was used in $86 \%$ of the treatment series, bitemporal treatment in $11 \%$, and bifrontal treatment in $3 \%$. Eleven percent of the patients in the quality register went on to receive outpatient continuation ECT after their index series.

The stimulus parameters for the electrical stimulus at first ECT were reported to the register in $60 \%$ of index series. The median stimulus is presented in Figure 2. In $13 \%$ of the treatment series the charge was $>576 \mathrm{mC}$.

Anesthesia was provided by an anesthesiologist in $41 \%$ of the hospitals and by an anesthesia nurse in $24 \%$ of the hospitals according to the survey. In the remaining hospitals, anesthesiologists and anesthesia nurses alternated. Propofol was used in $23 \%$ of the treatment series (median dosage $100 \mathrm{mg}$ ) and pentobarbital was used in the remaining $77 \%$ (median dosage $300 \mathrm{mg}$ ).

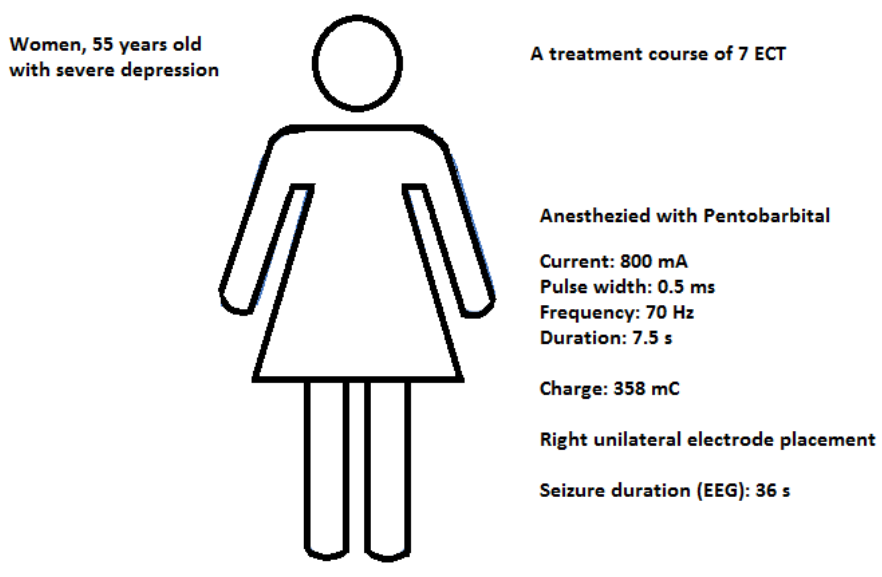

Figure 3. The most common ECT patient and treatment parameters in Sweden 2013 


\subsection{HIPPOCAMPAL VOLUME AND CBF IN RELATION TO CLINICAL AND COGNITIVE OUTCOME (PAPER II-IV)}

\subsubsection{Antidepressant treatment response (Paper III and IV)}

In the 12 subjects presented in paper II and III, remission (MADRS $<12$ ) was reached in $50 \%$ of the patients within one week after ending the ECT course. There was a significant reduction in both MADRS score (pre-post ECT mean reduction: 24.8, SD 11.4, confidence interval 17.6 - 32.1, $p<0.001$ ) and MADRS-self rating score (prepost ECT mean reduction: 16.7, SD 9.0, confidence interval 10.9- 22.4, $p<0.001$ ) after ECT, without further significant changes in the remaining subjects during the one year follow-up (figure 4).

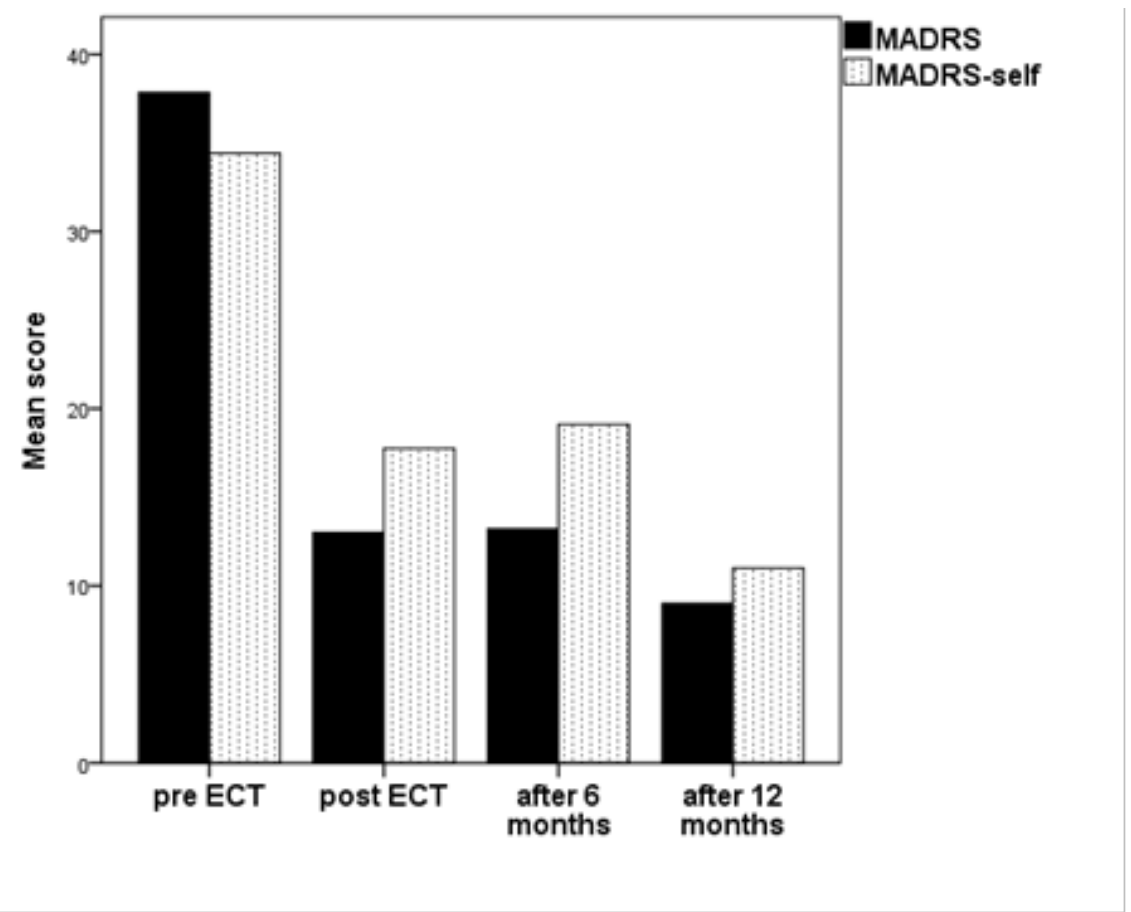

Figure 4. Montgomery Asberg Depression Rating scores (MADRS) and self- rating (MADRS-s) (paper III)

A significant reduction in MADRS ( $\mathrm{t}(13)=8, \mathrm{p}<0.001)$ and MADRS-S (t $(13)=7$, $\mathrm{p}<0.001)$ scores was seen also within two weeks after ending the ECT course in the 14 subjects presented in paper IV. Eight subjects reached remission, two reached the criteria for response, three partial response (43 - 49\% reduction in MADRS-score), and one did not respond at all to ECT (10 \% reduction in MADRS-score). 
Between the groups of remitters $(n=8)$ and non-remitters $(n=6)$ there were no significant differences in age, gender, pre-ECT MADRS score, numbers of ECT, or time-interval between last ECT and post-DSC-MRI (Table 4).

Table 4. Demographic data based on remitters vs non-remitters (Paper IV)

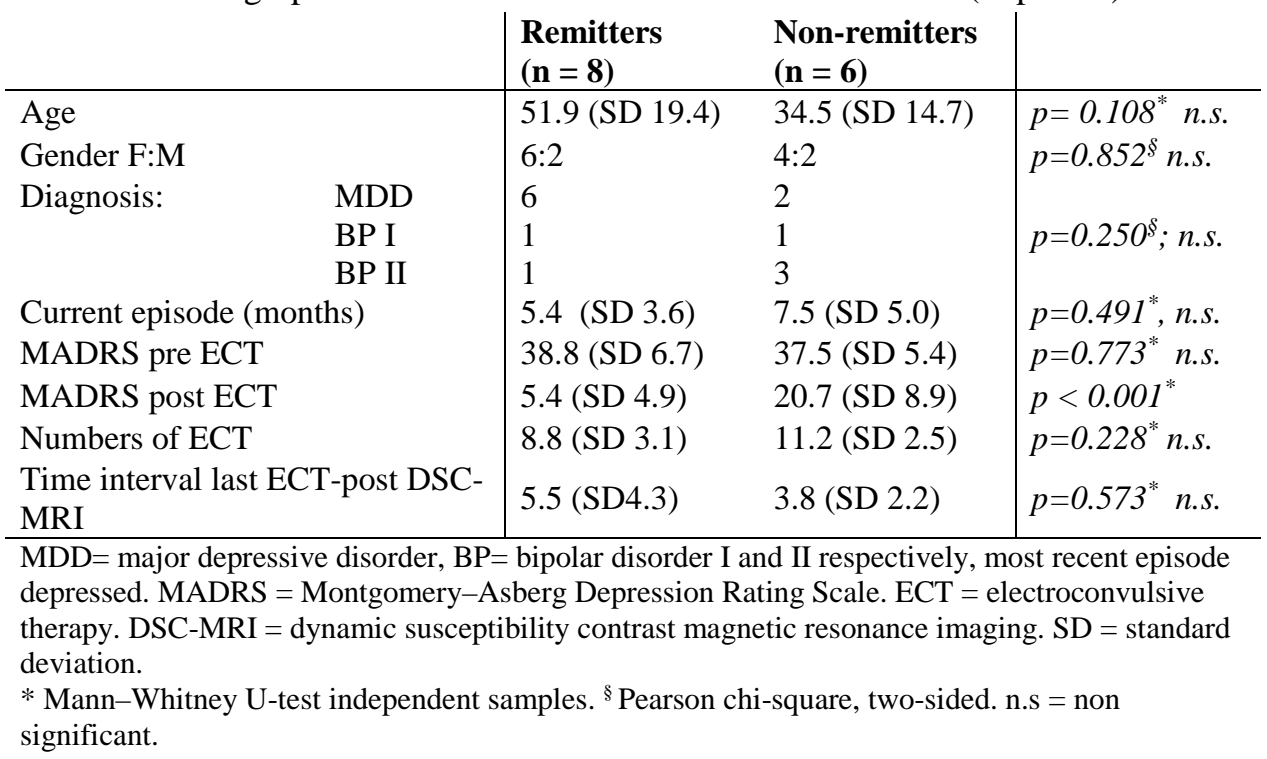

\subsubsection{Cognitive side-effects (Paper III)}

An overview of trends and significant changes in raw scores of each cognitive test is shown in Table 5.

There was no difference in performance in the vocabulary test at baseline and after one year (mean scale points 10 at both assessments, normative score $=10 \pm 2 \mathrm{SD}$ (Wechsler 1997a)).

Processing speed and attention (Digit symbol, TMT-A, Digit Span) tended to improve after ECT, reaching significance after six months in Digit symbol and TMT-A. The Stroop test also showed a trend towards improved performance after ECT, reaching significance after six months. Executive functioning according to the Verbal Fluency test, on the other hand, was significantly impaired $(\mathrm{p}<0.05)$ within one week after ECT; an impairment that also was reversed after six months. The same trend was seen in TMT-B but without significance. 
Significant decreases in performance within one week after ECT (A1-A2) were seen in the verbal episodic memory tests RAVLT Retention $\mathrm{p}<0.05)$, Delayed $(\mathrm{p}<0.01)$ and Recognition $(\mathrm{p}<0.05)$. This reduction was significantly reversed after six months post ECT (A2-A3, $p<0.05$ ) in RAVLT Retention and Recognition, returning to nonsignificant differences from baseline levels. According to RAVLT Delayed, a return to baseline levels close to significance was seen between the post ECT performance and six months later, with a p-value of 0.054 , but a true significant reversion of the decrease lasted until 12 months post ECT (A2-A4 $p<0.05)$. A trend towards a decrease in RAVLT Immediate was also seen immediately after ECT, and an increase after six and twelve months, but changes in this test did not reached significance at any time point. There was an overall non-significant trend towards improvement in all verbal episodic memory tests in the follow up assessments at six and twelve months, as compared to baseline performance.

Table 5. Arrows showing trends in mean raw score in paired sample test at different assessment points.

\begin{tabular}{|c|c|c|c|c|c|}
\hline & & $\begin{array}{l}\text { A1- } \\
\text { A2 } \\
n=12\end{array}$ & $\begin{array}{l}\text { A2- A3 } \\
n=10\end{array}$ & $\begin{array}{l}\text { A1-A3 } \\
n=10\end{array}$ & $\begin{array}{l}\text { A1-A4 } \\
n=7\end{array}$ \\
\hline Vocabulary & & & & & n.c. \\
\hline \multirow{6}{*}{$\begin{array}{l}\text { Processing speed, } \\
\text { attention and executive } \\
\text { functioning }\end{array}$} & Digit symbol & $\uparrow$ & $\uparrow * *$ & $\uparrow * *$ & $\uparrow^{*}$ \\
\hline & TMT-A & $\uparrow$ & $\uparrow$ & $\uparrow *$ & $\uparrow$ \\
\hline & Digit Span & $\uparrow$ & $\uparrow$ & $\uparrow$ & $\uparrow$ \\
\hline & Stroop test & $\uparrow$ & $\uparrow$ & $\uparrow * *$ & $\uparrow *$ \\
\hline & Verbal fluency & $\downarrow *$ & $\uparrow * *$ & $\uparrow$ & $\uparrow$ \\
\hline & TMT-B & $\downarrow$ & $\uparrow$ & $\uparrow$ & $\uparrow * *$ \\
\hline \multirow{4}{*}{ Verbal episodic memory } & RAVLT immediate & $\downarrow$ & $\uparrow$ & $\uparrow$ & $\uparrow$ \\
\hline & RAVLT retention & $\downarrow^{*}$ & $\uparrow *$ & $\uparrow$ & $\uparrow$ \\
\hline & RAVLT delayed & $\downarrow * *$ & $\uparrow$ & $\uparrow$ & $\uparrow$ \\
\hline & $\begin{array}{l}\text { RAVLT } \\
\text { recognition }\end{array}$ & $\downarrow *$ & $\uparrow *$ & $\uparrow$ & $\uparrow$ \\
\hline \multirow{3}{*}{ Visual episodic memory } & RCFT, immediate & & & & n.c. \\
\hline & RCFT, delayed & & & & n.c. \\
\hline & RCFT, recognition & & & & n.c. \\
\hline \multirow{2}{*}{ Spatial problem solving } & Block design & & & & $\uparrow$ \\
\hline & RCFT, copying & & & & n.c. \\
\hline
\end{tabular}

${ }^{*} \mathrm{p}<0.05, * * \mathrm{p}<0.001$

A1-A2= pre versus post ECT; A2-A3 = post ECT versus six months after ECT; A1-A3= pre ECT versus minimum six months post ECT; A1-A4= pre ECT versus minimum 12 months post ECT. n.c.= no change in mean raw score

Visual episodic memory (Rey Complex Figure tests, RCFT) showed no change at all in mean raw score from baseline values and one year after ECT. 
Spatial problem solving according to RCFT copying were unchanged according to mean raw score at baseline and after twelve months, in the Block Design Test there was a small and non-significant trend towards improvement.

In our study sample, performance was in the middle or higher span of the normal range during the follow up (six and twelve months) according to stanine or scale points, except for performance in RCFT. In the RCFT mean stanine points were in the lower range (mean stanine $=4$ ) both at baseline and after one year, without significant change.

\subsubsection{Hippocampal volume changes (Paper II and III)}

Hippocampal volume increased significantly both in the right $(t(11)=3.74, p<0.01)$ and left $(t(11)=6.58, p<0.001)$ side as well as when the two were combined $(p<0.001)$. No signal intensity changes were seen in the hippocampus in any of the patients on T2-weighted FLAIR images.

As shown in figure 5, the significant volume increase seen immediately after ECT returned to baseline levels after 6 months in both the right hippocampus $(t(9)=-2.65$, $p<0.05)$ and the left hippocampus $(t(9)=-3.38, p<0.01)$. There were no further significant changes after one year (between 6 and 12 months) and no significant differences between pre ECT hippocampal volumes and after 6 and 12 months respectively. 


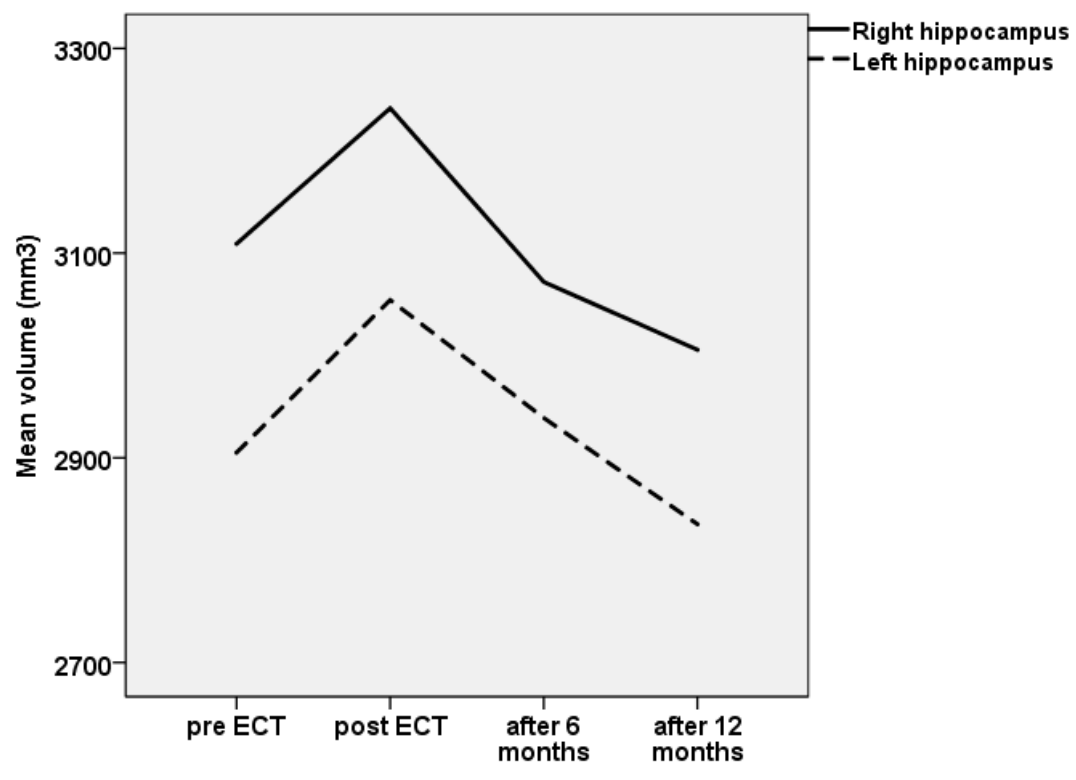

Figure 5. Mean hippocampal volume pre-post ECT $(\mathrm{n}=12)$, after 6 months $(\mathrm{n}=10)$ and after 12 months $(\mathrm{n}=7)$.

\subsubsection{Hippocampal volume in relation to treatment effect (Paper III)}

The increase pre-post ECT in the left hippocampal volume was positively correlated to numbers of ECT $(r=0.67, p<0.05)$, but this was not evident in the right hippocampus. Age or gender did not significantly correlate to this volume increase.

The return to baseline levels of $n$ hippocampal volumes after 6 and 12 months could not be correlated to any change in MADRS score.

\subsubsection{Hippocampal volume in relation to cognition (Paper III)}

The left hippocampal volume change pre-post ECT showed a significant positive correlation to improvement in the TMT-A test $(r=0.64, p<0.05)$. However, controlling for numbers of ECT erased this correlation. No other cognitive tests were associated with changes in hippocampal volumes, or numbers of ECT. 


\subsubsection{CBF after ECT (Paper IV}

A significant decrease in relative $\mathrm{CBF}$ was seen in the right lateral temporal lobe $(p<0.05)$. In the occipital lobe, the CBF increased significantly $(p<0.05)$. No significant differences were seen in any other ROI in the whole study group. There was a difference in the balance of CBF between right and left cerebellar hemispheres after ECT, with a right-sided increase after ECT $(p<0.05)$. The ratio between the frontal and occipital lobe was significantly decreased $(p<0.05)$.

\subsubsection{CBF after ECT, remitters vs. non-remitters (Paper IV)}

There were no significant changes in relative CBF after ECT in any ROI in the group of non-remitters. The occipital increase found in the analysis of the whole study group was seen only in the subgroup of remitters. In both subgroups, a trend towards a decrease in the right lateral temporal lobe was seen, but in neither group the decrease was significant. A significant relative decrease in the right frontal lobe $(p<0.05)$ after ECT was seen in the remitters, producing a significant difference between remitters and non-remitters. Analysis of ratios revealed a significant $(\mathrm{p}<0.05)$ difference in shift in the anterior/posterior lobe ratios (frontal/parietal and frontal/occipital) and the right/left deviation (frontal and cerebellar lobes) in cerebral blood flow between the 2 groups after ECT. 


\section{DISCUSSION}

\subsection{CLINICAL ASPECTS}

The use of ECT in Sweden (paper I) was found to be at the same rate as in the latest systematic review from 1975 (42 in 1975 versus 41 in 2013 / 100000 (Frederiksen and D'Elia 1979). Thus, despite the increased number of drugs used to treat severe mental illness, ECT remains an important treatment option in clinical practice. It is important to note that we have only taken into account the rate of use in relation to population and not in relation to the current prevalence of disorders treatable of ECT; therefore we cannot exclude the possibility that the use of ECT might be proportionally different in 2013 from 1975 due to epidemiological differences. In addition, there could be a bias according to type and accuracy of reporting to the mandatory register.

In a global perspective, Sweden has a relatively high availability of ECT (Leiknes et al. 2012), similar to that in Belgium (41 per 100000 inhabitants) (Sienaert et al. 2006) and Australia (40-44 per 100 000) (Wood and Burgess 2003, Chanpattana 2007). In contrast lower rates of use have recently been reported in Norway (24 per 100000 ) (Schweder et al. 2011), Slovakia (29 per 100 000) (Dragasek 2012) and Canada (23-25 per 100 000) (Martin et al. 2014). The rate of use in Germany 2008 was found to be as low as 3.5/ 100000 but increasing (Loh et al. 2013). This is in contrast to a recent study from the United States, where inpatient hospital care including ECT was estimated to be 7.2/100 000 and declining (Case et al. 2013). Although it seems that Sweden is a country with high rate of use of ECT in a global perspective, using occasional national surveys or a national mandatory register can produce bias in comparisons between countries. Sweden has in this aspect, a unique opportunity to provide reliable data of the national use of ECT.

The availability of ECT varies between counties in Sweden; the reasons for this difference still need to be elucidated. Regional variation within countries has been attributed to service factors or barriers to access, as well as regional treatment traditions (Nelson 2005, Schweder et al. 2011, Kaliora et al. 2013, Lookene et al. 2014, Martin et al. 2014). Different regional treatment traditions might also influence the within country availability in Sweden, as might the regional differences of availability of anesthesiologists and psychiatrists. National guidelines and national quality register have the intention to assure a more equal availability not depending on local traditions and service factors barriers. 
Our findings of the characteristics of the Swedish ECT population (paper I) are in accordance to data from other western countries (Leiknes et al. 2012), in the aspects that we find a predominance of women receiving ECT, with a median age above middle-age, and depression being the most common indications for ECT. This is in contrast to Asian countries, were the most common ECT patient is a young man with schizophrenia.

A high proportion of patients received ECT for indications that are in line with clinical guidelines (APA 2001, Nordanskog and Nordenskjold 2014). However, the pattern of use also shows that ECT is used, albeit sparse, in disorders where the treatment is not recommended. On the other hand, $62 \%$ of inpatients with a first-line indication for ECT according to Swedish clinical guidelines did not receive ECT. Taken together, these data shows that there is at the same time room for improvements both in the accuracy of patient selection and the availability of ECT.

Paper I also shows that ECT is often delivered by a nurse or even an attendant, and this is relatively unique for Sweden. There are no national mandatory regulations concerning the qualifications of the personnel delivering ECT, but the national guidelines provided in 2014 (Nordanskog and Nordenskjold 2014) do not support the delegation of ECT to attendants and recommend Swedish psychiatrists to be more involved in the delivery of ECT.

In our study, 13\% received ECT under the act of involuntary psychiatric treatment (Lag om psykiatrisk tvångsvård 1991:1128). There is no clear connection between treatment under the use of compulsory care and having ECT without consent. Written consent for ECT is common in Europe (Gazdag et al. 2012), but verbal consent is standard before medical and surgical procedures in Sweden, regulated in law (Patientlag 2014:821). Complete information to the patient is mandatory, patients right to self-determination and integrity must be respected, and medical care cannot be provided without the given consent (verbal or written) of the patient. If written consent were to be required only for ECT and not for other treatments, there is a risk that mental disease and ECT would be even more stigmatized than it is today. Moreover, in situations where the need for ECT is most urgent, the disease can sometimes prohibit decision-making. The requirement of a written consent could constitute a medical risk if it delays the treatment. Rather, as soon as it is possible, the patient and next of kin should be invited to participate in decisions regarding adjustments to optimize treatment benefit

Our study sample in paper II-IV appears to be most representative according to response and remission rates of ECT in depression in clinical settings (SBU 2004, Fink and Taylor 2007). Out of 14 subjects presented in paper IV, 13 respond to the treatment with symptom relief, of which 8 (57\%) are defined as being in remission within one week after ending the ECT course. 


\subsection{Cognitive ASPECTS}

The usefulness of ECT is claimed to be restricted due to its cognitive side effects and the question of whether they are fully reversible or to some extent permanent (Sackeim et al. 2007). Our findings confirm previous reports of a significant, acute impairment in verbal episodic memory and executive functions immediately after the ECT course, though none of the investigated cognitive domains showed persistent impairment when retested after 6 months. On contrary, performance in all cognitive tests tended to be improved at the 6 and 12 month follow-up assessments, compared to baseline performance. The external validity of our result is of course restricted due to our small study sample and high drop-out rate during the one year follow-up. However, our findings are in line with decades of research world-wide as well as meta-analytic findings (Semkovska and McLoughlin 2010)

Attention and processing speed tended to improve immediately after ECT. This could be of importance when addressing the question of differences in subjective and objective memory in ECT research (Prudic et al. 2000). Awareness of memory capacity, as well as interest or motivation in remembering, might be influenced by a depressed mood and the ability to attend and focus. During depression, there seems to be impairment in attention and processing speed. After ECT, these depression-related cognitive impairments subside, but instead a shortage in storage and retrieving verbal episodic memories appears. This shift in various cognitive domains involved in the ability to encode, store and retrieve memories affected by depression and ECT, respectively, might explain why during depression, the defect in cognitive functions does not always appears as a main problem for the individual patient, but the cognitive side-effects when in response after ECT do.

Still some patients report that they experience permanent memory impairment after receiving ECT. To date we do not have any answer to this, and neither did we find any long-term deficits related to the exposure to ECT, according to the validated neuropsychological tests used in our study. There are some questionnaires that have been used for autobiographic memory showing long-term impairments when using bitemporal ECT (Sackeim et al. 2007). However, these are without appropriate validation and thus, the interpretation of their findings scientifically questioned (Semkovska and McLoughlin 2013).

There are several different approaches to understanding patients' reports on permanent memory impairments after ECT, besides the aspect of a possible cognitive side-effect related to ECT.

First, depression, and other severe psychiatric disorders as delirious mania or catatonia, are potential sources for injuring the biological substrates in cognition. It is suggested that in some cases, cognitive dysfunction related to state (more pronounced 
in the more severe states of depression and the cumulative load) also remains after remission (Hasselbalch et al. 2012, Hasselbalch et al. 2013).

Second, in the light of psychological impact of subjective memory, the ECT-induced experience of verbal episodic memory impairment, if not addressed properly, might produce difficulties in getting over the experience. This may cause the development of a self-concept of being unable to remember, even though according to neuropsychological assessments, these deficits are transient. In addition, if ECT does not induce remission or response, then the subjective experience of the acute cognitive side-effects without any positive effects renders the experience of ECT only harmful. This scenario will be more likely if the indication for ECT is not correctly determined (i.e. an anxiety disorder or adjustment disorder being mistaken for a depression). This assumption further stresses the importance the accuracy in patient selection for ECT.

Third, in a recent study, ECT is shown to impair the reconsolidation of episodic memory; a stored memory that is reactivated immediately before an ECT is more sensitive than a non-reactivated memory (Kroes et al. 2014). Hypothetically, this suggests that an old memory that is reactivated will be as vulnerable as recent information and, in turn, could be impaired in the same extent in the acute side-effects which we relate to the anterograde amnesia.

In contrast to all other cognitive tests in our study sample, the performance in visual episodic memory according to RCFT was found to be in the lower range of normative data, both before and 12 month after ECT. This is a finding worth noting. It could implicate a possible trait or vulnerability related deficit in visual episodic memory or an impairment caused by the disorder itself, or even that ECT, when using unilateral non-dominant (right hemisphere) electrode placement, affects visual memory. 


\subsection{NEUROBIOLOGICAL ASPECTS}

\subsubsection{Hippocampal volume increase}

Our study confirmed for the first time a significant bilateral increase in hippocampal volume in ECT-treated patients with depression. Later, we also showed that this increase was followed by a return to baseline levels in the longitudinal course of 6 months and one year, without state-dependent relation to treatment efficacy or cognitive side-effects.

After we published our first findings in 2010, later studies have provided support for our result of an immediate effect of ECT on the integrity of the hippocampus of depressed patients. First, in 2013, Tendolkar et al. replicated our findings in a study with 15 antidepressant free patients (Tendolkar et al. 2013). Aside from a significant bilateral volume increase of both hippocampi, with no evidence of global brain volume increase (which we in our study had not controlled for), they also reported a volume increase in the amygdala. Second, in 2014 Abbott el al presented a study in an older patient cohort (inclusion criteria $>50$ years and mean age in study sample 65.3 year). In this population, they found only a right-sided increase, and suggested that predominant side of stimulation could be of importance. The laterality to a right sided hippocampus increase after ECT was also shown by Dukart et al. (Dukart et al. 2014), again suggesting a relation between side of stimulation and hippocampal volume increase. This hypothesis is not supported in our study, in which the increase in left hippocampus was more significant than in the right, despite a predominance of right unilateral treatments. Although we did not find any relation between age and amount of volume increase, the possibility of age-related limit of plasticity related volume increase cannot be excluded. Furthermore, in the study by Dukart et al, the time points between baseline (T1) and assessments at 3 (T2) and 6 months (T3) were not set in relation to the ECT course (ECT was provided either between T1-T2 or T2-T3 and without regards to if patients assessed presently received or had completed ECT), making the interpretation of the findings more difficult. In neither of these reports did the volume increase statistically correlate to the associated clinical effect. The largest MRI study sample size to date was presented by Joshi et al. (Joshi et al. 2015) in 2015, wherein 29 patients with a depressive episode were investigated immediate before and after ECT. They again replicated the finding of a significant bilateral hippocampal and amygdala volume increase. This study is the first, and currently only, study that has shown a significant correlation between the ECT associated hippocampal volume increase and clinical antidepressant efficacy. Their study sample was tapered off medications, and in contrast to the study by Tendolkar et al, wherein sedatives as benzodiazepines were allowed, no psychopharmacological treatment was used from baseline, during ECT, nor post-ECT assessment. 
This is of great importance, as they demonstrated that the hippocampal volume increase cannot be explained by a concomitant psychopharmacological treatment (as we in our study not can exclude), but is related to ECT. These more recent studies have also pointed out the importance of analyzing different regions in the hippocampus being sensitive to changes, with focus on the anterior region (Joshi et al. 2015) and dentate gyrus, Corny Ammonis 1 and subiculum (Abbott et al. 2014).

The most recent study, (Jorgensen et al. 2015), is the fifth study since our first report, with supportive evidence for an immediate bilateral hippocampal and amygdala increase as a treatment related effect of ECT. In addition, they replicated our finding that this increase is transient, as they also reported a normalization towards pre-ECT values at the third assessment four weeks after ECT. They also show a decrease (transient) in dorsolateral prefrontal cortex during treatment course, a finding that also is noted in the study by Dukart et al.

With 3T MRI volumetric measurements of hippocampus, it is not possible to characterize the different internal components constituting the hippocampal volume. The transient volume changes shown in our study, as well as in the study by Jorgensen et al (Jorgensen et al. 2015) could therefore be explained by a transient edema. However, edema is however often recognized on MRI images at inspection, and we did not find any evidence of edema in the hippocampus on T2-weighted FLAIR images. In a study by Kunigiri et al (Kunigiri et al. 2007), no increase in T2 relaxation time (corresponding to water content) in the hippocampus after ECT was detected, suggesting that macroscopic hippocampal edema is not a consequence with ECT. Jorgensen et al could show a reduced diffusivity with DTI in the hippocampus, supporting the hypothesis of an increased hippocampal density after ECT.

There is a lot of evidence from pre-clinical studies that cell proliferation in hippocampus occurs during various anti-depressive treatment methods, including electroconvulsive stimulation (ESC) (Madsen et al. 2000). It is not restricted only to neurogenesis, an increase in neuropil (synaptogenesis) as well as glia- and angiogenesis also occurs (Hellsten et al. 2005, Jansson et al. 2009, Kaae et al. 2012, Bouckaert et al. 2014) which could produce a mass-effect detectable as a volume increase with MRI. In a recent animal study, Kaae et al (Kaae et al. 2012) showed that ECS induces a detectable hippocampal volume increase, with a corresponding increase of number of neurons and glial cells. This finding supports the possibility that the volume increase immediately after ECT, in humans also consists of a morphological change and not only edema. An alternative approach regarding the neurobiological substrate behind the macroscopic hippocampal volume increase related to ECT is the use of ${ }^{1} \mathrm{H}$-MRS. An increase in the $1.28 \mathrm{ppm}$ resonance signal within hippocampus is suggested to provide support for an increase in neural stem cell and progenitor cells, but no such increase was seen in the study by Jorgensen et al. (Manganas et al. 2007, Jorgensen et al. 2015). 
At this pre-clinical explanation level, our findings also raise the question of the nonpersistence of the immediate volume increase after ECT at the follow-up, shown in our study and by Jorgensen et al (Jorgensen et al. 2015). If our volumetric increase is caused by cell proliferation, including synaptogenesis, the decline back to pretreatment volumes must be explained by an opposing mechanism. This may be related to a normal turnover processes related to cerebral plasticity, in which pruning and migration mechanisms decrease the volumetric effects of the initial treatment induced proliferation burst. However, it could also be related to the specific individuals that are investigated in these studies. The vast majority of patients have a recurrent affective disorder, unipolar or bipolar (in our study 12/12, in the study by Jorgensen at al 17/19 subjects). The decline back to pre-treatment hippocampal volumes may represent a vulnerability to depression, occurring before onset of recurrence of the disease and correlate to clinical findings of constitutional predisposing factors. For example, studies shows that a family history of depression and early-life stress without existence of any depressive episodes are associated with lower hippocampal volume (Rao et al. 2010, Amico et al. 2011). Another mechanism might be the wellknown link between hypercortisolemia in stress and depression (Pittenger and Duman 2008), causing structural changes hippocampus (Hellsten et al. 2002) but also in gross brain structures (Kellner et al. 1983), and such alterations may be reversible. Preclinical studies provide contradictory results, finding both evidence of an increased apoptosis after ECS (Ito et al. 2010), as well as lack of such an effect (Otabe et al. 2014).

The question if ECT could cause permanent morphological brain changes has been an important question in the field of psychiatric research. In our study, the detectable change in hippocampus immediately after ECT was transient; a finding that is in line with earlier studies which have not been able to detect permanent structural brain changes as an effect of ECT (Coffey et al. 1991, Devanand et al. 1994).

\subsubsection{Hippocampal volume in relation to treatment effect and cognitive findings}

At a clinical level, our findings point the question about hippocampal volume in depression as a pre-existing risk-factor (trait) or a biomarker of state. We found a significant improvement, according to MADRS score, in the study population, but could not find a significant correlation between this improvement and the individual hippocampal volume increase. Before controlling for numbers of ECT, the correlation even seemed to be negative in the right hippocampus. This result was unexpected, and not easily explained. Despite a significant ECT-associated anti-depressive response in all other later presented studies, only in one (Joshi et al. 2015), the ECT induced hippocampal increase significantly correlated to treatment efficacy. This study 
beholds the largest patient sample this far, which might be of importance as the ability to reach statistical significance improves with the power in the study. On the other hand, not in this study, nor any other thus far, our finding of an association between hippocampal volumes increase and the numbers of ECT has been further discussed.

One hypothetical explanation to the negative correlation to treatment outcome in our study, could be the fact that a subject not responding to ECT will have more treatments than a subject who respond, before it is decided that the treatment doesn't work. If the treatment itself, i.e. the numbers of ECT, causes the volume increase, individuals who respond to a lesser extent will have a greater increase and the correlation to treatment outcome will be negative. Our results are in line with both Frodl et al (Frodl et al. 2008) and Schermule et al (Schermuly et al. 2011) where hippocampal volume increase was associated with pharmacological anti-depressive treatment, without significantly corresponding to the degree of clinical anti-depressive response rate.

A correlation between verbal episodic memory tests and changes in hippocampal volumes is theoretically plausible, due to the importance of the hippocampus in episodic memory functions. However, we did not find a statistical correlation between the decrease in verbal episodic memory tests within one week after ECT, and the hippocampal volume increase. The reversal of this immediate memory impairment after 6 and 12 months did not correlate to the return to baseline levels of hippocampal volumes. In another study, patients successfully treated with antidepressants significantly improved in tests of verbal episodic memory without any significant changes in hippocampal volume. Though, in that study, time interval between assessments was 7 months (Vythilingam et al. 2004).

\subsubsection{Significant shifts in perfusion ratios after ECT}

To our knowledge this is the first longitudinal study of cerebral perfusion after ECT in patients with depression using the DSC-MRI technique. Our main finding is that a decrease of relative $\mathrm{CBF}$ in the right frontal lobe is significantly associated with clinical remission within 2 weeks after a course of ECT. Analysis of ratio scores also revealed a significant shift in the anterior-posterior $\mathrm{CBF}$ gradient and a hemispheric lateralization of the CBF in the remitters versus the non-remitters. Secondly, a decrease in $\mathrm{CBF}$ in the right temporal lobe was seen that was independent of the response after ECT.

Despite using a very different method for analysis of the CBF pattern and despite a small sample size, our results are very similar to those of Nobler et al. (Nobler et al. 1994). In their study, a pattern of ECT-induced hypofrontality was also associated with clinical response. Postulating that a decrease in CBF corresponds to a decrease in 
neural activity, these findings support the anticonvulsant hypothesis of the efficacy of ECT. In addition, Nobler et al showed that different electrode placements (RUL or $\mathrm{BT}$ ) resulted in different effects on hemispheric lateralization. RUL treatment resulted in reduction in anterior $\mathrm{CBF}$ restricted to the right side, whereas BT treatment resulted in symmetric CBF reduction. This dependence of electrode placement has also been shown in other studies (Prohovnik et al. 1986, McNally and Blumenfeld 2004) of CBF and ECT. As most of the treatments were RUL in our study, our finding of a rightsided change is also in line with the findings in the study by Nobler et al. (Nobler et al. 1994). However, our results suggest that this hemispheric lateralization might also relate to treatment outcome, as we found no change in right-left deviation in frontal and cerebellar lobes after ECT in the subgroup of non-remittent.

Subgroup analysis also revealed that the significant increase in the occipital lobe and the resulting decreased frontal-occipital ratio found in the whole study group were caused by the change in the subgroup of remitters. The only change that did not have any relationship to treatment outcome was the relative decrease in the right lateral temporal lobe, which was also seen as a trend in both subgroups, but it did not reach significant levels in any subgroup alone. The reason for this might be due to statistical limits in our small sample, with a smaller change in the right temporal lobe than in the right frontal and occipital lobes. Another hypothesis is that the decrease in the right temporal CBF is dependent on the treatment stimulation and not on antidepressant mechanisms.

Present knowledge indicates that changes in CBF and CMR vary depending on the time elapse between ECT and scanning (Bolwig 2014). During the ictal period of ECT, there is an increase in CBF (McNally and Blumenfeld 2004), with the increase being largest where stimulation has been provided (Blumenfeld et al. 2003), followed by a postictal or interictal decrease (Prohovnik et al. 1986, Segawa et al. 2006). This decrease then tends to recover gradually after the course of ECT has been completed (Navarro et al. 2002, Takano et al. 2006). In our study, subjects were investigated with a time span of 1 to 14 days between last ECT and post-ECT scanning. The time interval for the CBF recovery is not fully known, pointing out the impact of timing of post ECT scanning on the divergent results in different studies.

In studies on CMR after ECT, a decrease in glucose metabolism in bilateral anterior and posterior frontal regions has been the most consistent finding (Bolwig 2014). In studies of changes in blood flow after ECT, findings are, however, even more divergent and inconsistent (Zhuo and Yu 2014). There are several suggested explanations for this, besides the impact of timing of post-ECT scanning discussed above. Both diagnostic and demographic differences in studies and diverse modalities and imaging techniques ( ${ }^{133} \mathrm{Xe}$-inhalation or ${ }^{99 \mathrm{~m}}$ Tc-HMPAO SPECT or cerebral blood flow studies with PET) are possible explanations. Variations in methods of image analysis, such as voxel-by-voxel-based analysis versus ROI analysis, might produce 
different findings. Since a change in perfusion also occurs in the cerebellar regions after ECT, cerebellar normalization in a ROI analysis might give an inaccurate result (Takano et al. 2006) and should therefore be avoided. We used whole brain

normalization in this study. Also, different external factors, such as coffee intake and smoking, may affect the cerebral perfusion (Mathew and Wilson 1991, Dager and Friedman 2000). 


\subsection{METHODOLOGICAL CONSIDERATIONS}

Both studies in this thesis (paper I and paper II-IV) are observational and descriptive in their designs. In observational studies, random bias cannot be excluded. In paper IIIV, concomitant medicine may influence the results, as well as the inclusion of both bipolar and unipolar depression, the wide age-range and lack of control group. Some of these potential biases have been further investigated in more recent studies on hippocampal volume in depression treated with ECT. This demonstrates the importance of research communication and how the scientific society together processes important research questions using small differences in study methodology.

The national quality register for ECT had 85\% coverage of all ECT given in Sweden 2013 and reported to the mandatory register. This reduces the risk of selection bias according to results of variables described in this paper and gives a high reliability to our results. But although reporting ECT is to the national patient register is mandatory, the risk of deficits in reporting cannot be totally excluded.

Our findings in paper II-IV demands caution due to small sample size and statistical limits. A small number of participants increase the risk of making type II errors due to low statistical power. In addition, multiple assessments within a small study sample, which increases the risk of making type I errors.

Clinical long-term follow-up studies in patients with severe disorders entails several challenges, such as demanding ethical consideration in every individual detail in receiving an informed consent to participate. Studying clinical, cognitive, and neurobiological aspects in patients referred for ECT means the need of fast access to baseline assessments and not delaying treatment start. In discussion with colleagues within the same field of research, besides difficulties associated with the type of disorder studied, this need for a fast access to baseline assessments is the main reason for this type of study demanding several years of sampling in clinical settings and that despite the time taken, often small study samples are presented. The next difficulty is the high rate of drop-out during the follow-up, due to both clinical course, which includes not fulfilling the ECT-treatment or relapses, as well as not wanting to participate in MRI investigation more than one or two times.

These difficulties, which cause low statistical power must be approach through relating results to earlier studies in the field as well as repeated studies and multicenter collaborations. Despite our small sample size, our findings are strengthened by the fact that clinical and cognitive outcome are in line with earlier studies with higher statistical power and that our MRI-findings of the transient hippocampal volume increase have been replicated in repeated studies by different researchers.

In the volumetric analysis, the two raters' knowledge about the temporal condition of the volumetric assessment could raise suspicion on a possible experimenter expectancy effect. The major finding opposing the occurrence of such an effect is the 
heterogeneity of the assessments in which a few patients were found not to have an increased hippocampal volume or only a small increase. Another methodological problem is that motion artefacts impact the quality of images provided.

Regarding the neuropsychological assessments, we have only used valid tests done with experienced neuropsychologists given high reliability.

We used the MADRS for assessment of treatment response. There are no simple ways of judging response in psychiatric disorders, and the criteria determining whether a subject is in remission or just barely reaches the threshold for response is arbitrative and diffuse. A cut off score of 10 for remission according to MADRS has been recommended (Hawley et al. 2002), but a cut off score 12 is also often used especially in many pharmacological treatment studies. Response is mostly defined as a reduction in rating scores of $50 \%$ or more. But what is the clinical relevance if you have a $46 \%$ reduction in burden of symptoms, or 55\%? In our study, when comparing those with 12 or less in MADRS versus those with 13 or more after ECT, we found a biological difference in cerebral response to ECT. In the search for state biomarkers in depression a less strict approach according to clinical defined borderline ratings is necessary. 


\section{CONCLUSIONS AND FUTURE PERSPECTIVES}

At a clinical perspective, this thesis presents the first update on the clinical use and practice of ECT in Sweden since 1975. We can conclude that ECT remains an important treatment option in daily clinical everyday practice and that the rate of use in Sweden has not changed the last 40 years. International comparisons reveal a higher rate of use in Sweden than other countries, but bias due to methodological differences cannot be excluded. The selection of patients for ECT in Sweden and treatment technique is similar to that in other western countries, but the consent procedure and the involvement of nurses and nursing assistants in the delivery of ECT differ. There is room for improvement in the patient selection for ECT (specificity of use) and availability of ECT in disorders where ECT is considered a first-line treatment. The description of use of ECT in Sweden has important national clinical implications, both the need for improvements described, but also according to the discrepancy in availability between sites, gender and age. An important clinical implication is to spread this information to clinicians to obtain an accurate and available ECT practice in Sweden. There are also several questions with potential to further study within the national quality register of ECT. One is the question of how to improve the prediction of response to ECT. Despite fulfilling the study inclusion criteria, as well as being clinically considered to be benefitting from ECT by the clinically responsible psychiatrist, 1 out of 14 patients did not respond at all. Another important need for future studies is to investigate relationship between subjective experience of memory disturbances after receiving ECT and indications for treatment, as well as other practice parameters.

We found significant cognitive side-effects within one week of ending the course of ECT that were related to impairments in verbal episodic memory and executive tests, albeit these deficits were transient. After 6 and 12 months, all patients had a normal (in relation to normative data for each test) performance in all neuropsychological assessments. Due to our small study sample and a high-drop out, we cannot claim our cognitive findings to have a clinical implication of its own. But our within-subject design of a long-term follow up during one year is rare and of importance in regards to the question about eventual long-term side effects. Our results are also in line with many years of earlier neuropsychological research in ECT. A clinical patient sample in Sweden, receiving ECT for depression in the $21^{\text {th }}$ century, present the same pattern of cognitive side-effects both according to type and duration that has been reported as are shown in different studies from different sites in the world. One conclusion could be that the cognitive side-effects, i.e. impairment in verbal episodic memory and executive functioning, as they turn out to be transient, should not be claimed to restrict the use of ECT and that no risk of overuse of ECT exists, as there are no support for potential long-term harming cognitive side-effects. This is a problematic conclusion, as all aspects of the human memory likely are not yet fully known and how to assess it 
continuously evolves. Conclusions based on the present understanding of memory processing made thus far might be revised. Furthermore, despite the objective measurable return of the acute cognitive impairments, the experience of the transient anterograde amnesia might be subjectively worrying for a long time. The clinical conclusion and implication of our results is instead that ECT should not be underused due to magnified fear of devastating permanent cognitive side-effects, especially according to its high potential to restore cognitive functions impaired by the mental disorder it treat. But we still need caution to the potential cognitive side-effects, accuracy in the use of ECT, precision in treatment practice parameters, and a proper treatment when patients report an experience of memory disturbances.

Regarding the neurobiological aspects of ECT, our study on hippocampal volumes and ECT was novel in this field. Subsequent studies have confirmed our results of a significant volume increase following a course of ECT in depression. We suggest that our findings are in line with preclinical results and the plasticity hypothesis of mechanism of action of ECT, although the structural changes must be further described and the meaning of these neurobiological changes must be better understood. Using 7 Tesla imaging would be of interest, making analysis of the content in structural changes possible. Also, further structural MRI studies with a concomitant analysis of different MRI-techniques such as ${ }^{1} \mathrm{H}-\mathrm{MRS}$ and DTI and peripheral biomarkers of cell proliferation are methods to advance support for the neuroplasticity hypothesis.

We found no correlation between neither the treatment response, nor the cognitive outcome with the longitudinal hippocampal volume changes. Instead, our results suggest an association to the number of treatments, without relation to the side of stimulation. At this moment, a multi-center study is underway, with research teams over the world cooperating (Oltedal et al. 2015). Analyses of multi-center data and larger samples makes it possible to test more clinical variables (treatment parameters, effect and side-effects) in relation to structural changes than small samples can.

Our perfusion findings is of methodological importance, as the perfusion MRI is a safe and easier to perform than older assessments on cerebral blood flow. There are functional changes in cerebral blood flow with ECT, and we replicate earlier findings that a decreased frontal blood flow distinguishes remission from non-remission after ECT. If believing the hypothesis that cerebral blood flow relates to neuronal activity, this treatment response dependent shift in blood flow supports the anticonvulsive hypothesis of mechanism of action of ECT (postictal suppression reduces activity and blood flow). In addition, our finding matches the hyperconnectivity hypothesis of depression and the importance of a decreased functional connectivity in prefrontal regions for restoring a depressed mind. A decreased blood flow in the right temporal lobe was significant independent of an antidepressant response or not, making it a 
possible treatment related effect, especially as the majority of stimulations were rightsided unilateral.

In summary, at a clinical perspective this thesis provides important data on the present use and practice of ECT in Sweden. The thesis also further elucidates the cognitive side-effects of ECT in a long-term follow-up study design. In regards to finding important key features of the neurobiological mechanism of action of ECT, it also provides pioneering information on the hippocampal structural changes in relation to receiving ECT for depression in a clinical naturalistic setting, as well as supportive data on how the cerebral blood flow changes in relation to treatment and antidepressive response. 


\section{A personal proposal, way far from what presented results in this thesis scientifically can support. Still, this conclusion is drawn from literature, learning from experienced colleagues and my own clinical experience during the years of work.}

A disruption in the normal balance (or homeostasis, referring to where we began, in ancient Greece) in specific neurocircuits in brain underlies the clinical symptoms of depression. The involved neurocircuits are those responsible for emotion regulation and behavior, the default network (the "keynote" or basic tone in brain), cognition and autonomic regulation, with both hyper- and hypo activity in different parts of these circuits. Although the arisen imbalance may lead to a depressive state, the phenotype of an imbalance can also manifest as other known mental illnesses, such as a manic psychotic or a catatonic state. The specific phenotype of the imbalance that presents is potentially due to the location or magnitude of hyper- or hypo-activity within the circuits. It may have been triggered by some kind of exogenous or endogenous stress. Endogenous stress could include a dysregulated stress-hormone system, inflammation, toxic agents, or activation of a genetic risk factor. In the early phase of this imbalance, rest and physical activity, psychotherapy, monoaminergic or other pharmacologic support might be able to provide enough help in the struggle of regaining balance. But if too enduring or too intense, a breaking point is reached. The necessary tools in the brain for restoring this imbalance are, at this point, completely non-functional. Fortunately, the mechanism of turning off an epileptic seizure is still functioning, which is what we can take advantage of. When we induce a seizure to the brain, it will end with a powerful endogenous postictal suppression. The brain gets a moment of peace; time to restore and find a balance again. And if repeated, during every recovery after the seizure, bit by bit the over-activation in stress-hormone system and neuronal activity decreases and repairing mechanisms become involved. One of these repairing mechanisms is the neuronal plasticity, meaning the ability of the brain, its cells and networks to adapt and adjust to new challenges. In addition, in response to the emptying of stores during the seizure, the production of neurotransmitters increase. The restored ability to sleep, eat and even take a walk makes it possible for the healing process to proceed. I suggest that our findings presented in this thesis of a decreased frontal cerebral blood flow and hippocampal volume increase are consequences of repeated post-ictal suppressions.

But, no treatment is without side-effects, and a fast, induced proliferation burst in hippocampus disturbs the processes of learning and memory. A decreased cerebral blood flow means that functions that were not affected by the original neurocircuit imbalance also will be involved, as the postictal suppression is broad in the brain. Cognitive side-effects are a fact. In addition, a treatment that involves anesthesia is always associated with somatic risks, as are a seizure. This is why ECT must be 
handled with respectful professionalism and specificity in patient selection. But at the same time, no patient with potential benefit of ECT should be denied it.

Some scientists and colleagues nowadays again consider the electrical stimulation to be of most importance for the mechanism of action of ECT. It might have added a factor also contributing, when introduced in 1938, but I am totally convinced that the generalized epileptic seizure is the key in how ECT works, as are many with me, now and in the past.

In summary: ECT doesn't heal mental illness, it gives way for the endogenous healing processes to come through. The most important mechanism of action is the postictal peace.

Medicus curat, natura sanat. 


\section{SAMMANFATTNING PÅ SVENSKA (SUMMARY IN SWEDISH)}

Depression är en mycket vanlig sjukdom. Det finns olika typer och grader av depression, från lindriga former till svåra och livshotande tillstånd. Elektrokonvulsiv terapi (ECT) används över hela världen vid de svåraste och ibland livshotande tillstånden inom psykiatrin, inklusive de svårare formerna av depression. Behandlingen innebär att man under narkos och muskelavslappning utlöser ett krampanfall, vilket slutar av sig självt inom en minut. Trots att ECT använts i snart 80 år har vi fortfarande inte fullt ut förstått dess verkningsmekanismer.

Den här avhandlingen bidrar till ökad kunskap om ECT. Den innehåller den första uppdateringen på 40 år avseende hur ECT används i Sverige idag, ny kunskap rörande vad som händer i hjärnan när en depression behandlas med ECT och beskriver även behandlingens effekt samt minnesbiverkningar och deras långsiktiga förlopp.

Den svenska ECT-användningen år 2013 visade sig vara oförändrad sedan 1975. I likhet med övriga västvärlden var den vanligaste orsaken för behandling med ECT en svår depression. Fler kvinnor än män fick behandlingen, medelåldern var 55 år och i genomsnitt gavs 7 behandlingar i en behandlingsserie. Vi såg att ECT ibland används vid sjukdomstillstånd där ECT inte är förstahandsmetod, och vår slutsats är att patienturvalet för behandlingen kan preciseras bättre i klinisk verksamhet. Samtidigt erbjöds de svårast sjuka ECT i en lägre utsträckning än förväntat.

I en studie av biologiska effekter och minnesbiverkningar ingick fjorton patienter som fick behandling med ECT för en depression. De genomgick en magnetkamera undersökning av hjärnan före och efter behandling med ECT, samt vid uppföljning efter 6 och 12 månader. Skattningar av depressionssymtom och neuropsykologiska test avseende minnesfunktioner gjordes också vid alla fyra tillfällena.

Vi kunde som första forskargrupp i världen visa att volymen av ett område i hjärnan som kallas hippokampus, ökade signifikant direkt efter ECT, men också att volymen gick tillbaka till de ursprungliga värdena efter 6 månader. Vi kunde inte finna något samband mellan dessa volymförändringar och klinisk effekt av behandlingen eller minnesbiverkningar. Fler och större studier behövs för att förstå det här viktiga fyndet. En teori är att denna volymökning orsakas av att ECT stimulerar en återväxt av celler som varit skadade under depressionen.

13/14 patienter förbättrades efter ECT, av dem var 8 helt symtomfria direkt när behandlingen avslutades. Endast dessa 8 individer hade ett sänkt blodflöde i höger pannlob. Fyndet skulle kunna ha betydelse som markör för behandlingseffekt och skapar intressanta följdhypoteser kring effektens bakomliggande biologi.

Vissa delar av minnesförmågan var markant försämrade efter ECT (det språkliga händelseminnet och förmåga att utföra mer komplexa mentala processer). 
Andra delar av minnesförmågan tenderade att vara förbättrade direkt efter ECT jämfört med vid mätningen före ECT, under pågående depression (uppmärksamhet och mental snabbhet). Vid uppföljning efter 6 och 12 månader fanns ingen bestående sänkt prestation i något neuropsykologiskt test och vi konstaterar att den minnesbiverkan vi kunnat mäta med våra tester var övergående. Minnesfunktionen är fortfarande ofullständigt karaktäriserad, och framtida metoder för att mäta minnet kan ge andra resultat. Därför måste vi även fortsatt vara noggranna i användningen av ECT både vad gäller vilka tillstånd som ska behandlas med ECT samt hur vi ger behandlingen. 


\section{TACK (ACKNOWLEDGEMENTS)}

Detta avhandlingsarbete började många år innan jag blev doktorand, och bygger på tre olika händelser. För det första, en avgörande och stark upplevelse där jag som mycket skeptisk AT-läkare vid psykiatriska kliniken i Norrköping för första gången fick erfara hur ECT kunde rädda liv, nästan som trolleri. Men trots att metoden inte direkt var ny, så fanns det inte någon riktig förklaring till hur eller varför behandlingen fungerade, bara att det gjorde det. Frustrerande och oacceptabelt, mitt intresse för ECT var väckt. För det andra, ett sommarvikariat inom psykiatrin i Lund/Landskrona, tillsammans med en nybliven specialist, numera professor, i psykiatri, Anders

Tingström. Jag tjuvlyssnade på hans samtal med doktorander, och jag förstod att han forskade på ECT, på råttor. Det blev visst fler nervceller av ECT. Fantastiskt, här fanns äntligen några som verkade förstå vikten av att ta reda på mer om den här så effektiva men obegripliga behandlingsmetoden. För det tredje, en av de första dagarna på mitt jobb som klinisk amanuens för psykiatrikursen i Lund, när professor i geriatrisk psykiatri, Lars Gustafson kliver in på mitt kontor med inledningsrepliken: ”-Jahaja, och vad ska du forska på då?” Mitt svar: ”Ja, öh, nej, jag ska inte forska, mitt mål är att bli en bra kliniker”. Hur det sen gick till vet jag inte, bara att när han lämnade mitt rum så var det bestämt att jag skulle forska på ECT. Och en liten stund senare satt jag på Aki Johansons rum och skissade på en klinisk ECT-studie där vi skulle undersöka kliniska, neuropsykologiska och neurobiologiska effekter av ECT.

Men att detta skulle bli ett avhandlingsarbete, det tog lång tid för mig att förstå och acceptera, som den inbitne kliniker jag i grunden är. Och en flytt till Linköping kom emellan. Därför bygger den här avhandlingen på engagemang, handledning och stöd från många personer, som jag nu vill rikta mitt varmaste TACK till:

Professor Aki Johanson, Lunds Universitet, på vars initiativ, handledarskap och huvudansvar för den kliniska studien om ECT och depression detta avhandlingsarbete bygger. Ditt stöd, allt från möjliggörande av forskningstid till hoppingivande samtal när jag varit på väg att ge upp, har varit ovärderligt.

Professor Elna-Marie Larsson, Uppsala Universitet. Du har inte bara bidragit till metod, resultat och handledning, du har genom din förmåga att driva på och entusiasmera hjälpt mig att slutföra påbörjat arbete.

Huvudhandledare och biträdande professor Maria Engström, Linköpings Universitet. Du tog dig an mig i ett skede där allt stod och vägde. Det hade aldrig blivit någon forskarutbildning för min del utan din vägledning.

Örjan Smedby, professor och handledare, utan vars generösa hjälp jag aldrig hade kunnat genomföra min forskarutbildning samtidigt som jag haft mina kliniska plikter.

Hela teamet i Lund för all hjälp och stöd i det långa arbetet med den kliniska studien. Neuropsykolog Anna-Carin Thulin som ställde upp akut under ordinarie arbetsdag 
för neuropsykologisk testning av patienter innan ECT, och, lite mer planerat, vid uppföljningarna. Sjuksköterska Helene och skötare Anita vid ECT-enheten i Lund, som pålitligt dokumenterade och höll uppsikt över alla studiepatienter i kliniken. Sekreterare Helena Andersson som under studieperioden hjälpte till med all administration. Jimmy Lätt, Titti Owman och alla andra på MR-enheten i Lund. Mina ytterligt kompetenta medförfattare Ulf Dahlstrand, Magnus R Larsson och Linda Knutsson som också analyserade MRI-data, och Magnus tack för all statistisk rådgivning.

Mina övriga kollegor vid psykiatriska kliniken i Lund. Jag vill särskilt nämna Lena Nylander, Anders Nimeus, Lil Träskman Bendz, Marika Lindvall samt alla mina ST-kollegor. Ni har alla bidragit till både den här forskningen och till den fasta grund inom ämnet psykiatri som jag står på idag. Och Anders Tingström, tack för alla lärorika diskussioner och för att jag har fått vara med i din ECT-forskningsfamilj. Som du förstår var det avgörande, och jag hoppas på att fortsättning följer.

Annika Thorsell och Susanne Hilke, Linköpings universitet, som frikostigt ställde upp med kompetens, tid och utrustning för provanalyser. Resultaten hamnade inte i denna avhandling, men gav oss metodiken för framtida undersökningar. Och beträffande framtiden, så vill jag också rikta ett tack till professor i psykiatri och beroendemedicin vid Linköpings universitet, Markus Heilig, som med sin drivkraft och närvaro motiverat mig att bli klar, samt byggt en väg framåt att gå på. Jag ser fram emot fortsättningen!

Alla kollegor i hela Norden inom föreningen NACT, Nordic Association of Convulsive Therapy. Det har varit en stor ynnest att få vara en del av detta nätverk och möta ECT-forskare och kliniker från hela världen. Det har i högsta grad bidragit till förståelse för sammanhanget av det jag forskat på. Ett särskilt tack vill jag rikta till Håkan Odeberg. Och få personer kan inspirera till fortsatt arbete som professor Jan-Otto Ottosson - NU är den klar!

Via NACT träffade jag första gången också min medförfattare, vän, kollega och initiativtagare till kvalitetsregister ECT, överläkare och med.dr Axel Nordenskjöld, Örebro universitet. Din förmåga att få saker gjorda är beundransvärd, och det är en fröjd och ära att få samarbeta med dig. Jag är inte klar med det än, så du vet.

Medarbetare och medförfattare Tony Andersén, Niclas Bengtsson, Ullvi Båve, Martin Hultén, Lars von Knorring, Mikael Landén och Johan Lundberg samt övriga medarbetare inom kvalitetsregister ECT. Tack för era bidrag och kloka synpunkter samt gott samarbete. Jag vill även tacka alla regionala samordnare och alla medarbetare vid samtliga ECT enheter i Sverige för ert dagliga arbete med detta register, liksom statistiker Emil Gustafsson utan vars hjälp det hade varit omöjligt att bringa ordning på all data. 
Mina kära kollegor och medarbetare vid psykiatriska kliniken i Linköping. Utan ett stöttande, inspirerande, ifrågasättande och tålmodigt kollegium, ingen forskare och ingen avhandling. Tack! Elisabeth Skogh, vad gjorde jag utan dig, och ingen lunch skulle jag äta heller. Andrea Johansson Capusan, att få ha en kollega som både är intresserad av klinisk forskning och god öl, kan det bli bättre? Bengt-Olof Bengtsson, du inte bara stöttade forskningen i din roll som verksamhetschef, härefter har du fortsatt att ställa upp när klinik och forskning varit svåra att förena.

Utan en verksamhetschef som förstår vikten av sjukvårdens "tredje ben” - forskning finns heller ingen möjlighet att skriva en avhandling, tack Marita Ström.

Vän och kollega, sjuksköterska Anna Jakobsson vid ECT-enheten i Linköping, som med sin kompetens, sitt tålamod och sin förmåga att hålla struktur ("en sak i taget”) har hjälpt mig att slutföra detta arbete med bibehållen entusiasm parallellt med klinisk vardag. Du har min fulla beundran.

Leah Mayo and Charlotte Medley, for your generous help with last minute editing.

Vänner och familj - tack för att ni ger mig perspektiv och ett liv vid sidan av arbete och forskning.

Till mamma och pappa vill jag rikta min oändliga tacksamhet för att ni alltid funnits och finns där för mig och min familj. ”Tänk logiskt...”, ”Allting är relativt”, och ”Om man verkligen vill något, då ska man kämpa för det.” är några ord från min uppväxt som ofta återkommit under detta arbete. Tack för att ni gett mig liv och trygghet. Den här avhandlingen bygger på ert stöd, liksom på glada tillrop från min kära bror Oscar med familj. Oscar - du är bäst.

Lukas, Arvid och Signe, det här forskningsarbetet har pågått under princip hela er uppväxt. Få förskolebarn känner till ord som "hippokampus” och ”ECT”, men det gjorde ni (fast inte era lärare). Ni är den största källan till kärlek och glädje i mitt liv. Fortsätt att vara dem ni är!

Gunnar, tack för all handledning (frivillig såväl som ofrivillig...), språkgranskning och redigering, uppmuntran och tålamod genom åren. Tack för att du räddat datorn och annat när jag i vissa förtvivlade stunder varit väldigt nära att kasta allt i väggen. Tack för att jag får borsta tänderna tillsammans med dig, jag gör det gärna ett tag till. 


\section{REFERENCES}

Abbott, C. C., T. Jones, N. T. Lemke, P. Gallegos, S. M. McClintock, A. R. Mayer, J. Bustillo and V. D. Calhoun (2014). "Hippocampal structural and functional changes associated with electroconvulsive therapy response." Transl Psychiatry 4: e483.

Abrams, R. (2002). Electroconvulsive therapy. Oxford ; New York, Oxford University Press.

Ahdidan, J., L. B. Hviid, M. M. Chakravarty, B. Ravnkilde, R. Rosenberg, A. Rodell, H. StodkildeJorgensen and P. Videbech (2011). "Longitudinal MR study of brain structure and hippocampus volume in major depressive disorder." Acta psychiatrica Scandinavica 123: 211-219.

Amico, F., E. Meisenzahl, N. Koutsouleris, M. Reiser, H. J. Moller and T. Frodl (2011). "Structural MRI correlates for vulnerability and resilience to major depressive disorder." J Psychiatry Neurosci 36(1): 15-22.

APA (1994). Diagnostic and Statistical Manual of Mental Disorders. Washington DC, American Psychiatric Press.

APA (2001). The practice of electroconvulsive therapy. Recommendations for Treatment, Training and Privileging. Washington, D.C., American Psychiatric Association.

Awata, S., M. Konno, R. Kawashima, K. Suzuki, T. Sato, H. Matsuoka, H. Fukuda and M. Sato (2002). "Changes in regional cerebral blood flow abnormalities in late-life depression following response to electroconvulsive therapy." Psychiatry and clinical neurosciences 56(1): 31-40.

Baran, B., I. Bitter, G. S. Ungvari and G. Gazdag (2012). "The birth of convulsive therapy revisited: a reappraisal of Laszlo Meduna's first cohort of patients." J Affect Disord 136(3): 1179-1182.

Berton, O. and E. J. Nestler (2006). "New approaches to antidepressant drug discovery: beyond monoamines." Nat Rev Neurosci 7(2): 137-151.

Blumenfeld, H., M. Westerveld, R. B. Ostroff, S. D. Vanderhill, J. Freeman, A. Necochea, P. Uranga, T. Tanhehco, A. Smith, J. P. Seibyl, R. Stokking, C. Studholme, S. S. Spencer and I. G. Zubal (2003). "Selective frontal, parietal, and temporal networks in generalized seizures." Neuroimage 19(4): 1556-1566.

Bocchio-Chiavetto, L., R. Zanardini, M. Bortolomasi, M. Abate, M. Segala, M. Giacopuzzi, M. A. Riva, E. Marchina, P. Pasqualetti, J. Perez and M. Gennarelli (2006). "Electroconvulsive Therapy (ECT) increases serum Brain Derived Neurotrophic Factor (BDNF) in drug resistant depressed patients." Eur Neuropsychopharmacol 16(8): 620-624.

Boldrini, M., M. D. Underwood, R. Hen, G. B. Rosoklija, A. J. Dwork, J. John Mann and V. Arango (2009). "Antidepressants increase neural progenitor cells in the human hippocampus." Neuropsychopharmacology 34(11): 2376-2389.

Bolwig, T. G. (2011). "How does electroconvulsive therapy work? Theories on its mechanism." Can J Psychiatry 56(1): 13-18.

Bolwig, T. G. (2014). "Neuroimaging and electroconvulsive therapy: a review." The journal of ECT 30(2): 138-142.

Bora, E., B. J. Harrison, M. Yucel and C. Pantelis (2013). "Cognitive impairment in euthymic major depressive disorder: a meta-analysis." Psychol Med 43(10): 2017-2026.

Bouckaert, F., P. Sienaert, J. Obbels, A. Dols, M. Vandenbulcke, M. Stek and T. Bolwig (2014). "ECT: its brain enabling effects: a review of electroconvulsive therapy-induced structural brain plasticity." J ECT 30(2): 143-151.

Campbell, S., M. Marriott, C. Nahmias and G. M. MacQueen (2004). "Lower hippocampal volume in patients suffering from depression: a meta-analysis." Am J Psychiatry 161(4): 598-607.

Case, B. G., D. N. Bertollo, E. M. Laska, L. H. Price, C. E. Siegel, M. Olfson and S. C. Marcus (2013). "Declining use of electroconvulsive therapy in United States general hospitals." Biol Psychiatry 73(2): 119-126.

Chanpattana, W. (2007). "A questionnaire survey of ECT practice in Australia." The journal of ECT 23(2): 89-92. 
Chen, F., T. M. Madsen, G. Wegener and J. R. Nyengaard (2009). "Repeated electroconvulsive seizures increase the total number of synapses in adult male rat hippocampus." Eur Neuropsychopharmacol 19(5): 329-338.

Coffey, C. E., R. D. Weiner, W. T. Djang, G. S. Figiel, S. A. Soady, L. J. Patterson, P. D. Holt, C. E. Spritzer and W. E. Wilkinson (1991). "Brain anatomic effects of electroconvulsive therapy. A prospective magnetic resonance imaging study." Arch Gen Psychiatry 48(11): 1013-1021.

Cuijpers, P., N. Vogelzangs, J. Twisk, A. Kleiboer, J. Li and B. W. Penninx (2013). "Differential mortality rates in major and subthreshold depression: meta-analysis of studies that measured both." Br J Psychiatry 202(1): 22-27.

Czeh, B. and P. J. Lucassen (2007). "What causes the hippocampal volume decrease in depression? Are neurogenesis, glial changes and apoptosis implicated?" Eur Arch Psychiatry Clin Neurosci 257(5): 250-260.

Dager, S. R. and S. D. Friedman (2000). "Brain imaging and the effects of caffeine and nicotine." Ann Med 32(9): 592-599.

DeCarolis, N. A. and A. J. Eisch (2010). "Hippocampal neurogenesis as a target for the treatment of mental illness: a critical evaluation." Neuropharmacology 58(6): 884-893.

Devanand, D. P., A. J. Dwork, E. R. Hutchinson, T. G. Bolwig and H. A. Sackeim (1994). "Does ECT alter brain structure?" Am J Psychiatry 151(7): 957-970.

Dragasek, J. (2012). "Electroconvulsive therapy in Slovakia." The journal of ECT 28(2): e7-8.

Drevets, W. C., J. L. Price and M. L. Furey (2008). "Brain structural and functional abnormalities in mood disorders: implications for neurocircuitry models of depression." Brain structure \& function 213(1-2): 93-118.

Dukart, J., F. Regen, F. Kherif, M. Colla, M. Bajbouj, I. Heuser, R. S. Frackowiak and B. Draganski (2014). "Electroconvulsive therapy-induced brain plasticity determines therapeutic outcome in mood disorders." Proc Natl Acad Sci U S A 111(3): 1156-1161.

Duman, R. S. (2004). "Depression: a case of neuronal life and death?" Biological psychiatry 56(3): 140-145.

Duman, R. S., S. Nakagawa and J. Malberg (2001). "Regulation of adult neurogenesis by antidepressant treatment." Neuropsychopharmacology 25(6): 836-844.

Duthie, A. C., J. S. Perrin, D. M. Bennett, J. Currie and I. C. Reid (2015). "Anticonvulsant Mechanisms of Electroconvulsive Therapy and Relation to Therapeutic Efficacy." J ECT.

Duvernoy, H. M. (2005). The human hippocampus : functional anatomy, vascularization, and serial sections with MRI. Berlin ; New York, Springer.

Eriksson, P. S., E. Perfilieva, T. Bjork-Eriksson, A. M. Alborn, C. Nordborg, D. A. Peterson and F. H. Gage (1998). "Neurogenesis in the adult human hippocampus." Nat Med 4(11): 1313-1317.

Faedda, G. L., I. Becker, A. Baroni, L. Tondo, E. Aspland and A. Koukopoulos (2010). "The origins of electroconvulsive therapy: Prof. Bini's first report on ECT." J Affect Disord 120(1-3): 12-15.

Ferrari, A. J., F. J. Charlson, R. E. Norman, S. B. Patten, G. Freedman, C. J. Murray, T. Vos and H. A. Whiteford (2013). "Burden of depressive disorders by country, sex, age, and year: findings from the global burden of disease study 2010." PLoS Med 10(11): e1001547.

Fink, M. (2001). "Convulsive therapy: a review of the first 55 years." J Affect Disord 63(1-3): 1-15.

Fink, M. (2014). "What was learned: studies by the consortium for research in ECT (CORE) 19972011." Acta Psychiatr Scand 129(6): 417-426.

Fink, M. and M. A. Taylor (2007). "Electroconvulsive therapy: evidence and challenges." JAMA 298(3): 330-332.

Frederiksen, S. O. and G. D'Elia (1979). "Electroconvulsive therapy in Sweden." The British journal of psychiatry : the journal of mental science 134: 583-587.

Frodl, T., M. Jager, I. Smajstrovla, C. Born, R. Bottlender, T. Palladino, M. Reiser, H. J. Moller and E. M. Meisenzahl (2008). "Effect of hippocampal and amygdala volumes on clinical outcomes in major depression: a 3-year prospective magnetic resonance imaging study." Journal of psychiatry \& neuroscience: JPN 33: 423-430.

Gazdag, G., R. Takacs, G. S. Ungvari and P. Sienaert (2012). "The practice of consenting to electroconvulsive therapy in the European Union." The journal of ECT 28(1): 4-6. 
Goodwin, F. K. and G. Jamison (2007). Manic-Depressive Illness: Bipolar Disorders and Recurrent Depression, 2nd Edition. New York, Oxford University Press.

Hamilton, M. (1959). "The assessment of anxiety states by rating." Br J Med Psychol 32(1): 50-55. Hamilton, M. (1960). "A rating scale for depression." J Neurol Neurosurg Psychiatry 23: 56-62.

Hasselbalch, B. J., U. Knorr, S. G. Hasselbalch, A. Gade and L. V. Kessing (2012). "Cognitive deficits in the remitted state of unipolar depressive disorder." Neuropsychology 26(5): 642-651.

Hasselbalch, B. J., U. Knorr, S. G. Hasselbalch, A. Gade and L. V. Kessing (2013). "The cumulative load of depressive illness is associated with cognitive function in the remitted state of unipolar depressive disorder." Eur Psychiatry 28(6): 349-355.

Hawley, C. J., T. M. Gale, T. Sivakumaran and g. Hertfordshire Neuroscience Research (2002). "Defining remission by cut off score on the MADRS: selecting the optimal value." J Affect Disord 72(2): 177-184.

Hellsten, J., M. Wennstrom, P. Mohapel, C. T. Ekdahl, J. Bengzon and A. Tingstrom (2002). "Electroconvulsive seizures increase hippocampal neurogenesis after chronic corticosterone treatment." Eur J Neurosci 16(2): 283-290.

Hellsten, J., M. J. West, A. Arvidsson, J. Ekstrand, L. Jansson, M. Wennstrom and A. Tingstrom (2005). "Electroconvulsive seizures induce angiogenesis in adult rat hippocampus." Biol Psychiatry 58(11): 871-878.

Henn, F. A. and B. Vollmayr (2004). "Neurogenesis and depression: etiology or epiphenomenon?" Biol Psychiatry 56(3): 146-150.

Ito, M., T. Seki, J. Liu, K. Nakamura, T. Namba, Y. Matsubara, T. Suzuki and H. Arai (2010). "Effects of repeated electroconvulsive seizure on cell proliferation in the rat hippocampus." Synapse 64(11): 814-821.

Jansson, L., M. Wennstrom, A. Johanson and A. Tingstrom (2009). "Glial cell activation in response to electroconvulsive seizures." Prog Neuropsychopharmacol Biol Psychiatry 33(7): 1119-1128.

Jelovac, A., E. Kolshus and D. M. McLoughlin (2013). "Relapse following successful electroconvulsive therapy for major depression: a meta-analysis." Neuropsychopharmacology 38(12): 24672474.

Jorgensen, A., P. Magnusson, L. G. Hanson, T. Kirkegaard, H. Benveniste, H. Lee, C. Svarer, J. D. Mikkelsen, A. Fink-Jensen, G. M. Knudsen, O. B. Paulson, T. G. Bolwig and M. B. Jorgensen (2015). "Regional brain volumes, diffusivity, and metabolite changes after electroconvulsive therapy for severe depression." Acta Psychiatr Scand.

Joshi, S. H., R. T. Espinoza, T. Pirnia, J. Shi, Y. Wang, B. Ayers, A. Leaver, R. P. Woods and K. L. Narr (2015). "Structural Plasticity of the Hippocampus and Amygdala Induced by Electroconvulsive Therapy in Major Depression." Biol Psychiatry.

Kaae, S. S., F. Chen, G. Wegener, T. M. Madsen and J. R. Nyengaard (2012). "Quantitative hippocampal structural changes following electroconvulsive seizure treatment in a rat model of depression." Synapse 66(8): 667-676.

Kaliora, S. C., R. J. Braga, G. Petrides, J. Chatzimanolis, G. N. Papadimitriou and I. M. Zervas (2013). "The practice of electroconvulsive therapy in Greece." The journal of ECT 29(3): 219-224.

Kellner, C. H., R. G. Knapp, G. Petrides, T. A. Rummans, M. M. Husain, K. Rasmussen, M. Mueller, H. J. Bernstein, K. O'Connor, G. Smith, M. Biggs, S. H. Bailine, C. Malur, E. Yim, S. McClintock, S. Sampson and M. Fink (2006). "Continuation electroconvulsive therapy vs pharmacotherapy for relapse prevention in major depression: a multisite study from the Consortium for Research in Electroconvulsive Therapy (CORE)." Arch Gen Psychiatry 63(12): 1337-1344.

Kellner, C. H., D. R. Rubinow, P. W. Gold and R. M. Post (1983). "Relationship of cortisol hypersecretion to brain CT scan alterations in depressed patients." Psychiatry Res 8(3): 191197.

Knutsson, L., S. Borjesson, E. M. Larsson, J. Risberg, L. Gustafson, U. Passant, F. Stahlberg and R. Wirestam (2007). "Absolute quantification of cerebral blood flow in normal volunteers: correlation between Xe-133 SPECT and dynamic susceptibility contrast MRI." Journal of magnetic resonance imaging: JMRI 26(4): 913-920. 
Kohn, Y., N. Freedman, H. Lester, Y. Krausz, R. Chisin, B. Lerer and O. Bonne (2007). "99mTc-HMPAO SPECT study of cerebral perfusion after treatment with medication and electroconvulsive therapy in major depression." Journal of nuclear medicine : official publication, Society of Nuclear Medicine 48(8): 1273-1278.

Kozorovitskiy, Y. and E. Gould (2003). "Adult neurogenesis: a mechanism for brain repair?" J Clin Exp Neuropsychol 25(5): 721-732.

Kritchevsky, M., J. Chang and L. R. Squire (2004). "Functional amnesia: clinical description and neuropsychological profile of 10 cases." Learn Mem 11(2): 213-226.

Kroes, M. C., I. Tendolkar, G. A. van Wingen, J. A. van Waarde, B. A. Strange and G. Fernandez (2014). "An electroconvulsive therapy procedure impairs reconsolidation of episodic memories in humans." Nat Neurosci 17(2): 204-206.

Kunigiri, G., P. N. Jayakumar, N. Janakiramaiah and B. N. Gangadhar (2007). "MRI T(2) relaxometry of brain regions and cognitive dysfunction following electroconvulsive therapy." Indian J Psychiatry 49(3): 195-199.

Lee, R. S., D. F. Hermens, M. A. Porter and M. A. Redoblado-Hodge (2012). "A meta-analysis of cognitive deficits in first-episode Major Depressive Disorder." J Affect Disord 140(2): 113124.

Leiknes, K. A., L. Jarosh-von Schweder and B. Hoie (2012). "Contemporary use and practice of electroconvulsive therapy worldwide." Brain and behavior 2(3): 283-344.

Lezak, M. D. (2012). Neuropsychological assessment. Oxford ; New York, Oxford University Press.

Lihua, P., M. Su, W. Ke and P. Ziemann-Gimmel (2014). "Different regimens of intravenous sedatives or hypnotics for electroconvulsive therapy (ECT) in adult patients with depression." Cochrane Database Syst Rev 4: CD009763.

Loh, N., T. Nickl-Jockschat, A. J. Sheldrick and M. Grozinger (2013). "Accessibility, standards and challenges of electroconvulsive therapy in Western industrialized countries: a German example." World J Biol Psychiatry 14(6): 432-440.

Lookene, M., A. Kisuro, V. Maciulis, V. Banaitis, G. S. Ungvari and G. Gazdag (2014). "Use of electroconvulsive therapy in the Baltic states." The world journal of biological psychiatry: the official journal of the World Federation of Societies of Biological Psychiatry 15(5): 419424.

Machado-Vieira, R., P. Yuan, N. Brutsche, N. DiazGranados, D. Luckenbaugh, H. K. Manji and C. A. Zarate, Jr. (2009). "Brain-derived neurotrophic factor and initial antidepressant response to an N-methyl-D-aspartate antagonist." The Journal of clinical psychiatry 70(12): 1662-1666.

MacQueen, G. and T. Frodl (2011). "The hippocampus in major depression: evidence for the convergence of the bench and bedside in psychiatric research?" Mol Psychiatry 16(3): 252264.

MacQueen, G. M., S. Campbell, B. S. McEwen, K. Macdonald, S. Amano, R. T. Joffe, C. Nahmias and L. T. Young (2003). "Course of illness, hippocampal function, and hippocampal volume in major depression." Proc Natl Acad Sci U S A 100(3): 1387-1392.

Madsen, T. M., A. Treschow, J. Bengzon, T. G. Bolwig, O. Lindvall and A. Tingstrom (2000). "Increased neurogenesis in a model of electroconvulsive therapy." Biol Psychiatry 47(12): 1043-1049.

Malberg, J. E., A. J. Eisch, E. J. Nestler and R. S. Duman (2000). "Chronic antidepressant treatment increases neurogenesis in adult rat hippocampus." J Neurosci 20(24): 9104-9110.

Maletic, V., M. Robinson, T. Oakes, S. Iyengar, S. G. Ball and J. Russell (2007). "Neurobiology of depression: an integrated view of key findings." Int J Clin Pract 61(12): 2030-2040.

Manganas, L. N., X. Zhang, Y. Li, R. D. Hazel, S. D. Smith, M. E. Wagshul, F. Henn, H. Benveniste, P. M. Djuric, G. Enikolopov and M. Maletic-Savatic (2007). "Magnetic resonance spectroscopy identifies neural progenitor cells in the live human brain." Science 318(5852): 980-985.

Marano, C. M., P. Phatak, U. R. Vemulapalli, A. Sasan, M. R. Nalbandyan, S. Ramanujam, S. Soekadar, M. Demosthenous and W. T. Regenold (2007). "Increased plasma concentration of brainderived neurotrophic factor with electroconvulsive therapy: a pilot study in patients with major depression." J Clin Psychiatry 68(4): 512-517. 
Martin, B. A., N. J. Delva, P. Graf, C. Gosselin, M. W. Enns, I. Gilron, M. Jewell, J. S. Lawson, R. Milev, S. Patry and P. K. Chan (2014). "Delivery of Electroconvulsive Therapy in Canada: A First National Survey Report on Usage, Treatment Practice, and Facilities." The journal of ECT.

Mathew, R. J. and W. H. Wilson (1991). "Substance abuse and cerebral blood flow." Am J Psychiatry 148(3): 292-305.

McEwen, B. S. (2005). "Glucocorticoids, depression, and mood disorders: structural remodeling in the brain." Metabolism 54(5 Suppl 1): 20-23.

McNally, K. A. and H. Blumenfeld (2004). "Focal network involvement in generalized seizures: new insights from electroconvulsive therapy." Epilepsy \& behavior : E\&B 5(1): 3-12.

Meier, P. and K. L. Zierler (1954). "On the theory of the indicator-dilution method for measurement of blood flow and volume." Journal of applied physiology 6(12): 731-744.

Montgomery, S. A. and M. Asberg (1979). "A new depression scale designed to be sensitive to change." Br J Psychiatry 134: 382-389.

Morris, R. G. (2006). "Elements of a neurobiological theory of hippocampal function: the role of synaptic plasticity, synaptic tagging and schemas." Eur J Neurosci 23(11): 2829-2846.

Murrough, J. W., B. lacoviello, A. Neumeister, D. S. Charney and D. V. Iosifescu (2011). "Cognitive dysfunction in depression: neurocircuitry and new therapeutic strategies." Neurobiol Learn Mem 96(4): 553-563.

Naidich, T. P., D. L. Daniels, V. M. Haughton, P. Pech, A. Williams, K. Pojunas and E. Palacios (1987). "Hippocampal formation and related structures of the limbic lobe: anatomic-MR correlation. Part II. Sagittal sections." Radiology 162(3): 755-761.

Navarro, V., C. Gasto, F. Lomena, J. J. Mateos, T. Marcos and M. J. Portella (2002). "Normalization of frontal cerebral perfusion in remitted elderly major depression: a 12-month follow-up SPECT study." Neurolmage 16(3 Pt 1): 781-787.

Navarro, V., C. Gasto, F. Lomena, J. J. Mateos, M. J. Portella, G. Massana, M. Bernardo and T. Marcos (2004). "Frontal cerebral perfusion after antidepressant drug treatment versus ECT in elderly patients with major depression: a 12-month follow-up control study." The Journal of clinical psychiatry 65(5): 656-661.

Nelson, A. I. (2005). "A national survey of electroconvulsive therapy use in the Russian Federation." The journal of ECT 21(3): 151-157.

Nobler, M. S., H. A. Sackeim, I. Prohovnik, J. R. Moeller, S. Mukherjee, D. B. Schnur, J. Prudic and D. P. Devanand (1994). "Regional cerebral blood flow in mood disorders, III. Treatment and clinical response." Archives of general psychiatry 51(11): 884-897.

Nordanskog, P. and A. Nordenskjold (2014). Kliniska riktlinjer för elektrokonvulsiv terapi, Gothia Fortbildning $A B$.

Oltedal, L., U. Kessler, L. Ersland, R. Gruner, O. A. Andreassen, J. Haavik, P. I. Hoff, A. Hammar, A. M. Dale, K. Hugdahl and K. J. Oedegaard (2015). "Effects of ECT in treatment of depression: study protocol for a prospective neuroradiological study of acute and longitudinal effects on brain structure and function." BMC Psychiatry 15: 94.

Otabe, H., M. Nibuya, K. Shimazaki, H. Toda, G. Suzuki, S. Nomura and K. Shimizu (2014).

"Electroconvulsive seizures enhance autophagy signaling in rat hippocampus." Prog Neuropsychopharmacol Biol Psychiatry 50: 37-43.

Pagnin, D., V. de Queiroz, S. Pini and G. B. Cassano (2004). "Efficacy of ECT in depression: a metaanalytic review." J ECT 20(1): 13-20.

Perera, T. D., J. D. Coplan, S. H. Lisanby, C. M. Lipira, M. Arif, C. Carpio, G. Spitzer, L. Santarelli, B. Scharf, R. Hen, G. Rosoklija, H. A. Sackeim and A. J. Dwork (2007). "Antidepressant-induced neurogenesis in the hippocampus of adult nonhuman primates." J Neurosci 27(18): 48944901.

Petrides, G., M. Fink, M. M. Husain, R. G. Knapp, A. J. Rush, M. Mueller, T. A. Rummans, K. M. O'Connor, K. G. Rasmussen, Jr., H. J. Bernstein, M. Biggs, S. H. Bailine and C. H. Kellner (2001). "ECT remission rates in psychotic versus nonpsychotic depressed patients: a report from CORE." J ECT 17(4): 244-253. 
Piccinni, A., A. Del Debbio, P. Medda, C. Bianchi, I. Roncaglia, A. Veltri, S. Zanello, E. Massimetti, N. Origlia, L. Domenici, D. Marazziti and L. Dell'Osso (2009). "Plasma Brain-Derived Neurotrophic Factor in treatment-resistant depressed patients receiving electroconvulsive therapy." Eur Neuropsychopharmacol 19(5): 349-355.

Pittenger, C. and R. S. Duman (2008). "Stress, depression, and neuroplasticity: a convergence of mechanisms." Neuropsychopharmacology 33(1): 88-109.

Preston, A. R. and H. Eichenbaum (2013). "Interplay of hippocampus and prefrontal cortex in memory." Curr Biol 23(17): R764-773.

Price, J. L. and W. C. Drevets (2010). "Neurocircuitry of mood disorders." Neuropsychopharmacology 35(1): 192-216.

Prohovnik, I., H. A. Sackeim, P. Decina and S. Malitz (1986). "Acute reductions of regional cerebral blood flow following electroconvulsive therapy. Interactions with modality and time." Annals of the New York Academy of Sciences 462: 249-262.

Prudic, J., M. Olfson, S. C. Marcus, R. B. Fuller and H. A. Sackeim (2004). "Effectiveness of electroconvulsive therapy in community settings." Biol Psychiatry 55(3): 301-312.

Prudic, J., S. Peyser and H. A. Sackeim (2000). "Subjective memory complaints: a review of patient self-assessment of memory after electroconvulsive therapy." J ECT 16(2): 121-132.

Rao, U., L. A. Chen, A. S. Bidesi, M. U. Shad, M. A. Thomas and C. L. Hammen (2010). "Hippocampal changes associated with early-life adversity and vulnerability to depression." Biol Psychiatry 67(4): 357-364.

Rasmussen, K. G. (2009). "Sham electroconvulsive therapy studies in depressive illness: a review of the literature and consideration of the placebo phenomenon in electroconvulsive therapy practice." J ECT 25(1): 54-59.

Rempp, K. A., G. Brix, F. Wenz, C. R. Becker, F. Guckel and W. J. Lorenz (1994). "Quantification of regional cerebral blood flow and volume with dynamic susceptibility contrast-enhanced MR imaging." Radiology 193(3): 637-641.

Sackeim, H. A. (1999). "The anticonvulsant hypothesis of the mechanisms of action of ECT: current status." J ECT 15(1): 5-26.

Sackeim, H. A., J. Prudic, R. Fuller, J. Keilp, P. W. Lavori and M. Olfson (2007). "The cognitive effects of electroconvulsive therapy in community settings." Neuropsychopharmacology 32(1): 244254.

Sahay, A. and R. Hen (2007). "Adult hippocampal neurogenesis in depression." Nat Neurosci 10(9): 1110-1115.

Santarelli, L., M. Saxe, C. Gross, A. Surget, F. Battaglia, S. Dulawa, N. Weisstaub, J. Lee, R. Duman, O. Arancio, C. Belzung and R. Hen (2003). "Requirement of hippocampal neurogenesis for the behavioral effects of antidepressants." Science 301(5634): 805-809.

SBU (2004). Behandling av depressionssjukdomar. http://www.sbu.se/sv/Publicerat/Gul/Behandlingav-depressionssjukdomar/ (2009).

SBU (2004). Behandling av depressionssjukdomar. En systematisk litteraturöversikt. . S. b. f. m. utvärdering. Stockholm: Kapitel 7. Elektrokonvulsiv behandling vid depression. .

Schermuly, I., D. Wolf, K. Lieb, P. Stoeter and A. Fellgiebel (2011). "State dependent posterior hippocampal volume increases in patients with major depressive disorder." Journal of affective disorders 135: 405-409.

Schweder, L. J., S. Lydersen, B. Wahlund, P. Bergsholm and O. M. Linaker (2011). "Electroconvulsive therapy in Norway: rates of use, clinical characteristics, diagnoses, and attitude." The journal of ECT 27(4): 292-295.

Segawa, K., H. Azuma, K. Sato, T. Yasuda, K. Arahata, K. Otsuki, J. Tohyama, T. Soma, T. lidaka, S. Nakaaki and T. A. Furukawa (2006). "Regional cerebral blood flow changes in depression after electroconvulsive therapy." Psychiatry research 147(2-3): 135-143.

Semkovska, M. and D. M. McLoughlin (2010). "Objective cognitive performance associated with electroconvulsive therapy for depression: a systematic review and meta-analysis." Biol Psychiatry 68(6): 568-577. 
Semkovska, M. and D. M. McLoughlin (2013). "Measuring retrograde autobiographical amnesia following electroconvulsive therapy: historical perspective and current issues." J ECT 29(2): 127-133.

Sheehan, D. V., Y. Lecrubier, K. H. Sheehan, P. Amorim, J. Janavs, E. Weiller, T. Hergueta, R. Baker and G. C. Dunbar (1998). "The Mini-International Neuropsychiatric Interview (M.I.N.I.): the development and validation of a structured diagnostic psychiatric interview for DSM-IV and ICD-10." J Clin Psychiatry 59 Suppl 20: 22-33;quiz 34-57.

Sheline, Y. I., J. L. Price, Z. Yan and M. A. Mintun (2010). "Resting-state functional MRI in depression unmasks increased connectivity between networks via the dorsal nexus." Proc Natl Acad Sci U S A 107(24): 11020-11025.

Sheline, Y. I., M. Sanghavi, M. A. Mintun and M. H. Gado (1999). "Depression duration but not age predicts hippocampal volume loss in medically healthy women with recurrent major depression." J Neurosci 19(12): 5034-5043.

Shimizu, E., K. Hashimoto, N. Okamura, K. Koike, N. Komatsu, C. Kumakiri, M. Nakazato, H. Watanabe, N. Shinoda, S. Okada and M. Iyo (2003). "Alterations of serum levels of brainderived neurotrophic factor (BDNF) in depressed patients with or without antidepressants." Biol Psychiatry 54(1): 70-75.

Shorter, E. and D. Healy (2007). Shock therapy : a history of electroconvulsive treatment in mental illness. New Brunswick, N.J., Rutgers University Press.

Sienaert, P., M. Dierick, G. Degraeve and J. Peuskens (2006). "Electroconvulsive therapy in Belgium: a nationwide survey on the practice of electroconvulsive therapy." Journal of affective disorders 90(1): 67-71.

Silfverskiold, P., L. Gustafson, J. Risberg and I. Rosen (1986). "Acute and late effects of electroconvulsive therapy. Clinical outcome, regional cerebral blood flow, and electroencephalogram." Annals of the New York Academy of Sciences 462: 236-248.

Socialstyrelsen (2010). "ECT-treatment, a pilot study " Socialstyrelsen (Artikel nr 2010-4-3). Available at http://www.socialstyrelsen.se/publikationer2010/2010-4-3 (assessed December 1, 2010).

Spalding, K. L., O. Bergmann, K. Alkass, S. Bernard, M. Salehpour, H. B. Huttner, E. Bostrom, I. Westerlund, C. Vial, B. A. Buchholz, G. Possnert, D. C. Mash, H. Druid and J. Frisen (2013). "Dynamics of hippocampal neurogenesis in adult humans." Cell 153(6): 1219-1227.

Stracciari, A., C. Fonti and M. Guarino (2008). "When the past is lost: focal retrograde amnesia. Focus on the "functional" form." Behav Neurol 20(3): 113-125.

Svanborg, P. and M. Asberg (1994). "A new self-rating scale for depression and anxiety states based on the Comprehensive Psychopathological Rating Scale." Acta Psychiatr Scand 89(1): 21-28.

Swartz, C. (2009). Electroconvulsive and neuromodulation therapies. Cambridge ; New York, Cambridge University Press.

Swartz, C. M., Ed. (2009). Electroconvulsive and neuromodulation therapies, Cambridge University Press.

Takano, H., M. Kato, A. Inagaki, K. Watanabe and H. Kashima (2006). "Time course of cerebral blood flow changes following electroconvulsive therapy in depressive patients--measured at 3 time points using single photon emission computed tomography." The Keio journal of medicine 55(4): 153-160.

Tendolkar, I., M. van Beek, I. van Oostrom, M. Mulder, J. Janzing, R. O. Voshaar and P. van Eijndhoven (2013). "Electroconvulsive therapy increases hippocampal and amygdala volume in therapy refractory depression: a longitudinal pilot study." Psychiatry Res 214(3): 197-203.

The UK ECT Review Group (2003). "Efficacy and safety of electroconvulsive therapy in depressive disorders. a systematic review and meta-analysis." Lancet 361: 799-808.

Wagner, S., C. Muller, I. Helmreich, M. Huss and A. Tadic (2015). "A meta-analysis of cognitive functions in children and adolescents with major depressive disorder." Eur Child Adolesc Psychiatry 24(1): 5-19.

Watson, C., F. Andermann, P. Gloor, M. Jones-Gotman, T. Peters, A. Evans, A. Olivier, D. Melanson and G. Leroux (1992). "Anatomic basis of amygdaloid and hippocampal volume measurement by magnetic resonance imaging." Neurology 42(9): 1743-1750. 
Wechsler, D. (1958). The measurement and Appraisal of Adult Intelligence. Baltimore:, Williams and Wilkins;.

Wechsler, D. (1997a). Wechsler Adult Intelligent Scale-III. San Antonio, TX, Psychological Corporation.

WHO (2008). "The Global Burden of Disease 2004 - Update."

WHO. (2015). "ICD-10 Version 2015. Available at http://apps.who.int/classifications/icd10/browse/2015/en."

Videbech, P. and B. Ravnkilde (2004). "Hippocampal volume and depression: a meta-analysis of MRI studies." Am J Psychiatry 161(11): 1957-1966.

Wood, D. A. and P. M. Burgess (2003). "Epidemiological analysis of electroconvulsive therapy in Victoria, Australia." The Australian and New Zealand journal of psychiatry 37(3): 307-311.

Wu, O., L. Ostergaard, W. J. Koroshetz, L. H. Schwamm, J. O'Donnell, P. W. Schaefer, B. R. Rosen, R. M. Weisskoff and A. G. Sorensen (2003). "Effects of tracer arrival time on flow estimates in MR perfusion-weighted imaging." Magn Reson Med 50(4): 856-864.

Wulsin, L. R., G. E. Vaillant and V. E. Wells (1999). "A systematic review of the mortality of depression." Psychosom Med 61(1): 6-17.

Vythilingam, M., E. Vermetten, G. M. Anderson, D. Luckenbaugh, E. R. Anderson, J. Snow, L. H. Staib, D. S. Charney and J. D. Bremner (2004). "Hippocampal volume, memory, and cortisol status in major depressive disorder: effects of treatment." Biol Psychiatry 56(2): 101-112.

Zhuo, C. and C. Yu (2014). "Functional Neuroimaging Changes Subsequent to Electroconvulsive Therapy in Unipolar Depression: A Review of the Literature." The journal of ECT.

Zierler, K. L. (1965). "Equations for Measuring Blood Flow by External Monitoring of Radioisotopes." Circulation research 16: 309-321. 



\section{Papers}

The articles associated with this thesis have been removed for copyright reasons. For more details about these see:

http://urn.kb.se/resolve?urn=urn:nbn:se:liu:diva-121458 